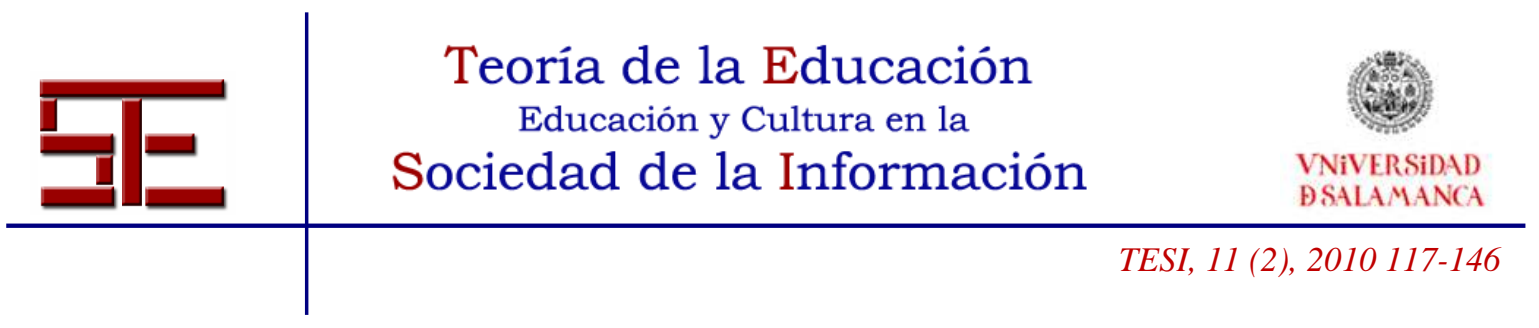

\title{
ENSEÑANZA ELECTRÓNICA DE RADIOLOGÍA EN PREGRADO: LA EXPERIENCIA DE LA UNIVERSIDAD DE MÁLAGA
}

\section{Resumen:}

Desde 1998, se desarrollan en la Universidad de Málaga recursos electrónicos de enseñanza y aprendizaje de Radiología. Se presentan algunas experiencias relacionadas con la enseñanza de Radiología en pregrado: unas prácticas de radiología autodirigidas, denominadas "Un Paseo por la Radiología", proyectos que proporcionan material de consulta sobre radiología, un proyecto sobre clases virtuales con audio (AMERAM), iniciado en 2005, y un portal Web cuyo objetivo es recopilar recursos educativos en Internet.

Finalmente, se aportan algunas reflexiones sobre la experiencia de estos años, que ha contribuido a mejorar el aprendizaje de los estudiantes de radiología en nuestro centro y ha proporcionado herramientas de formación a estudiantes y postgraduados de esta y otras ciudades. Consideramos que la filosofía de aprendizaje del Espacio Europeo de Enseñanza Superior, centrada en el alumno y basada en el autoaprendizaje, da una importancia vital a las herramientas electrónicas de formación en pregrado.

Palabras clave: Enseñanza electrónica, aprendizaje electrónico, multimedia, radiología, estudiantes de pregrado.

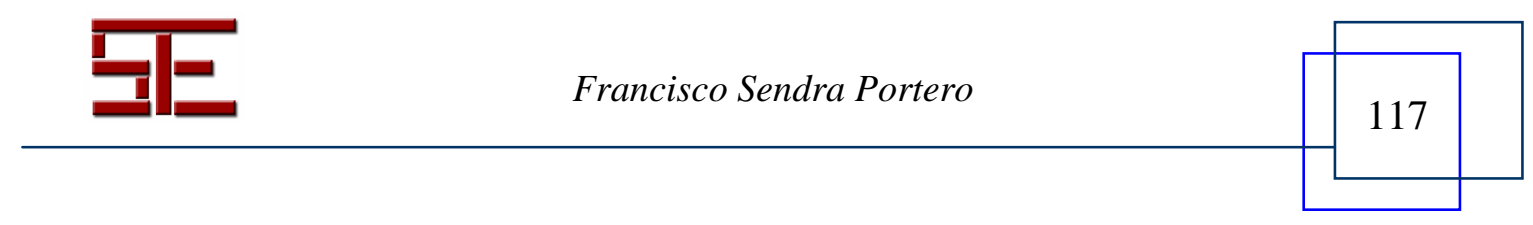




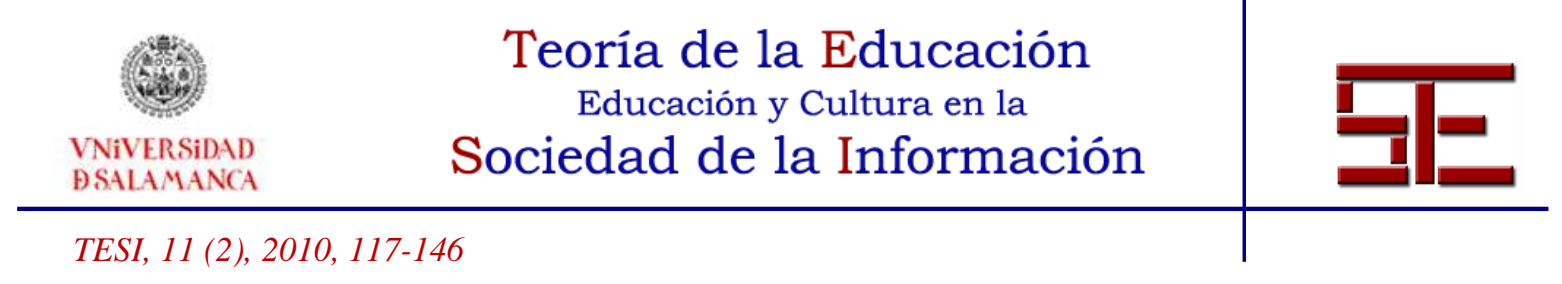

\title{
ELECTRONIC EDUCATION IN UNDERGRADUATE RADIOLOGY: THE EXPERIENCE OF THE UNIVERSITY OF MALAGA
}

\begin{abstract}
:
Since 1998, radiology teaching and learning electronic resources have been developed at the University of Málaga. Some experiences on undergraduate radiology education are presented in this paper: a self-conducted training on radiology called "A Walk through Radiology", some projects to create and develop radiology consulting tools, a project about audio-recorded virtual lectures (AMERAM), started on 2005, and a Web portal to collect radiology education Internet resources.

Finally, we conclude with some reflections about the experience along these years, which has contributed to improve the student's radiology learning in our centre and has supplied educative tools to students and postgraduates of this and other cities. We consider that the European Space of Higher Education learning philosophy, student centered and self-learning based, gives a vital role to undergraduate electronic education tools.
\end{abstract}

Keywords: Electronic education, e-learning, multimedia, radiology, undergraduate students

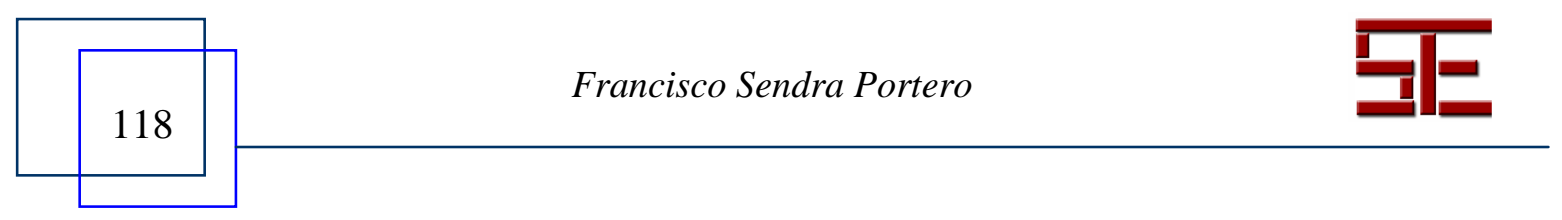




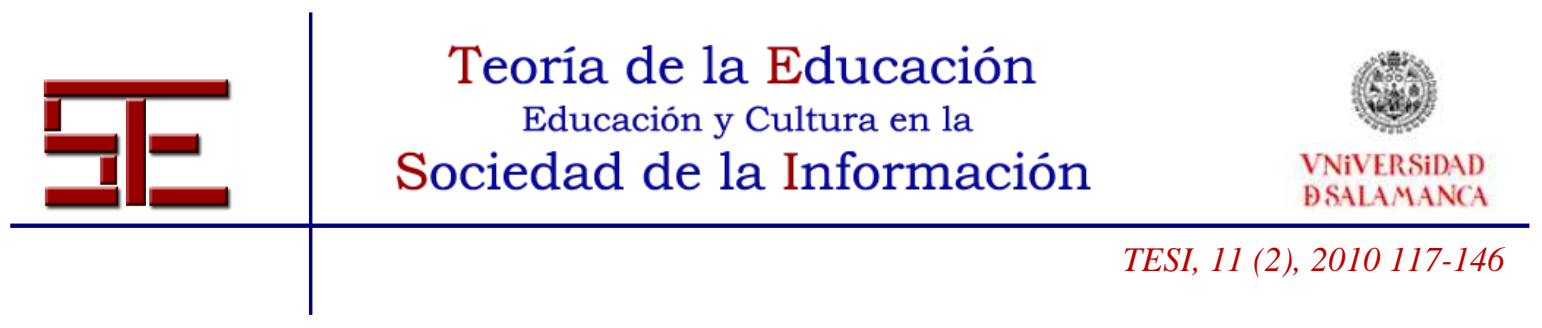

\title{
ENSEÑANZA ELECTRÓNICA DE RADIOLOGÍA EN PREGRADO: LA EXPERIENCIA DE LA UNIVERSIDAD DE MÁLAGA
}

Fecha de recepción: 07/09/2009; fecha de aceptación: 03/05/2010; fecha de publicación: 05/07/2010

\author{
Francisco Sendra Portero \\ sendra@uma.es \\ Universidad de Málaga
}

\section{1.-INTRODUCCIÓN}

En 1998, se comenzaron a desarrollar en el Departamento de Radiología y Medicina Física de la Universidad de Málaga recursos electrónicos de enseñanza y aprendizaje de Radiología, tanto para su utilización en CD-ROM (off-line) como para el aprendizaje on-line, mediante acceso a Internet. En este artículo se presentan algunos de estos proyectos como ejemplo de las posibilidades que la enseñanza electrónica de Radiología permite. Unos están dedicados exclusivamente al pregrado y otros a la enseñanza de postgrado, habiéndose explorado la utilidad que tienen para los alumnos de medicina. Todos los proyectos editados o de acceso on-line tienen su correspondiente página Web, donde se puede obtener información adicional. Desde la dirección http://wwwrayos.medicina.uma.es/eao/eao.htm se puede acceder a las mismas.

Desde un punto de vista técnico, varios de los proyectos que se presentan están basados en explotar las capacidades de PowerPoint como herramienta multimedia, yendo más allá de su uso como apoyo a las presentaciones orales. PowerPoint permite diseñar presentaciones para ser utilizadas por el usuario, quien decide el avance y los saltos que va a realizar en los contenidos, mediante botones y vínculos enlazados. Durante estos años hemos acumulado experiencia en este tipo de aplicaciones, algunas han sido difundidas y editadas (Martínez Morillo y Sendra Portero, 2000, 2002; Navarro Sanchis y Sendra Portero 2006), otras aún están pendientes de edición.

Se presentan unas prácticas de radiología autodirigidas, denominadas "Un Paseo por la Radiología" y algunos proyectos que proporcionan material de consulta sobre técnicas o aspectos particulares del diagnóstico radiológico. También se presenta un proyecto sobre clases virtuales con audio que se utiliza en la enseñanza reglada de Radiología, el proyecto AMERAM, iniciado en 2005, así como un portal Web cuyo objetivo es

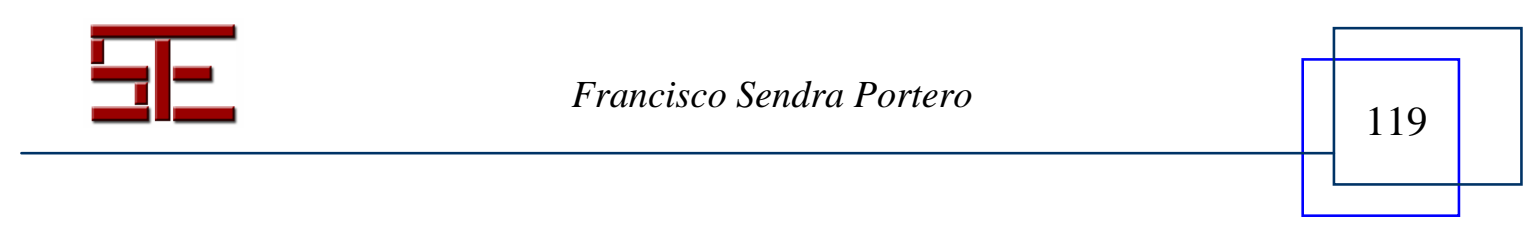




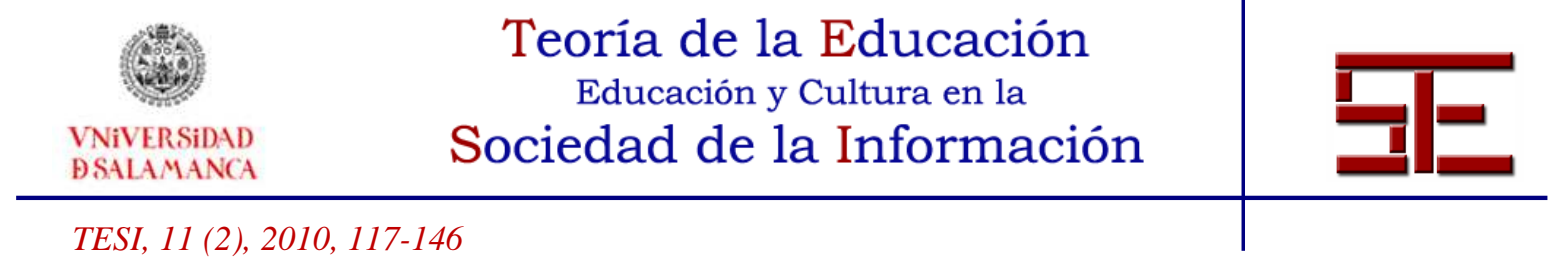

recopilar para los alumnos recursos educativos en Internet. Finalmente, se aportan algunas reflexiones sobre la experiencia de estos años.

Actualmente continúan desarrollándose sucesivas versiones y mejoras de los proyectos en curso y se exploran otras posibilidades del e-learning en Radiología que no se incluyen en la presente revisión.

\section{2.- PRÁCTICAS AUTODIRIGIDAS. UN PASEO POR LA RADIOLOGÍA.}

Un Paseo por la Radiología es un proyecto de prácticas de radiodiagnóstico asistidas por ordenador, iniciado en 1998, cuyo objetivo docente es proporcionar entrenamiento visual en la detección de hallazgos normales y anormales en las principales modalidades radiológicas. El enlace a la página Web del proyecto, es http://wwwrayos.medicina.uma.es/eao/PaseoRX.htm

Cuando se diseñó, se requería una aplicación fácilmente modificable, con una interfaz cómoda, empleando botones de desplazamiento e hipervínculos, de forma que el usuario se condujera exclusivamente con el ratón. La aplicación se realizó en PowerPoint y está divida en dos colecciones, una de imágenes normales y otra de imágenes patológicas.

El proyecto tiene como antecedente unas prácticas que se realizaban en nuestro departamento entre 1985 y 1998, con un visor de microfichas y pequeñas tarjetas de cartón con diapositivas incluidas en ellas (Fig. 1). El alumno debía leer el texto correspondiente a cada caso y después ir viendo las imágenes, con el fin de reconocer lo que se describía en el texto.

Un Paseo por la Radiología es una práctica autodirigida en la que el alumno debe trabajar identificando la técnica radiológica y la proyección de cada caso que se le presenta. Debe reconocer la localización de los elementos anatómicos fundamentales que se solicitan en los casos normales e identificar donde se encuentra la lesión o lesiones, que características tienen y a que patología podrían corresponder en los patológicos. En los años iniciales, 1998 y siguientes, se habilitó un aula con ordenadores para que los alumnos realizaran la práctica en grupos de 2 alumnos por ordenador (Fig. 2). Con el tiempo, la distribución en CD-ROM, la disponibilidad de ordenadores personales y las versiones html y flash que permiten la ejecución de la práctica on-line han hecho que dicha aula sea prescindible.

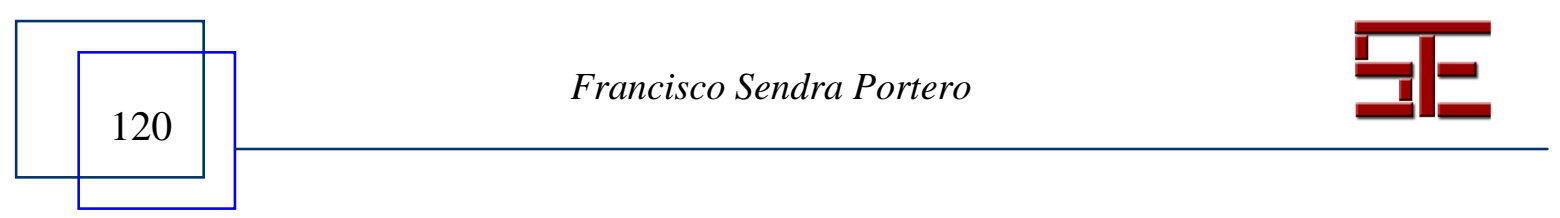




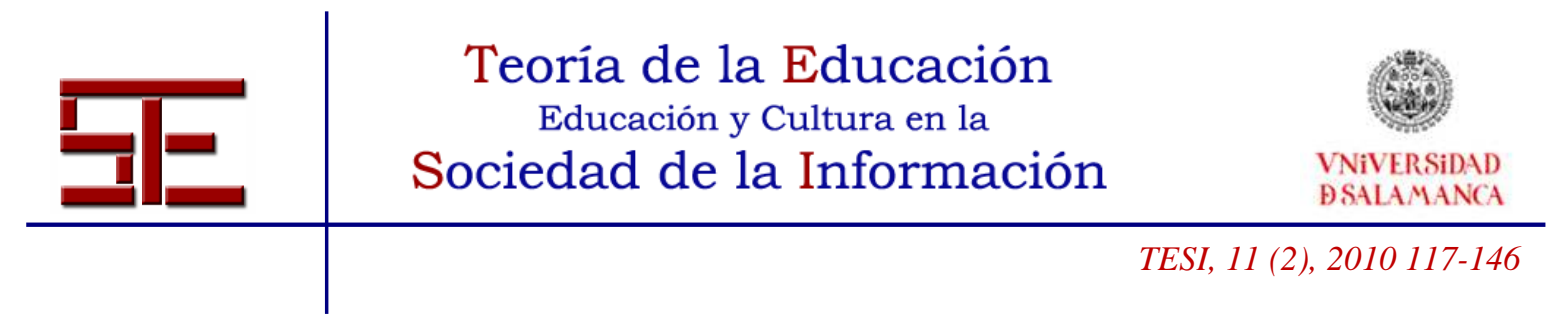

Antecedentes

Tarjetas $y$ visores

empleadas en prácticas

previas (1985-1998)
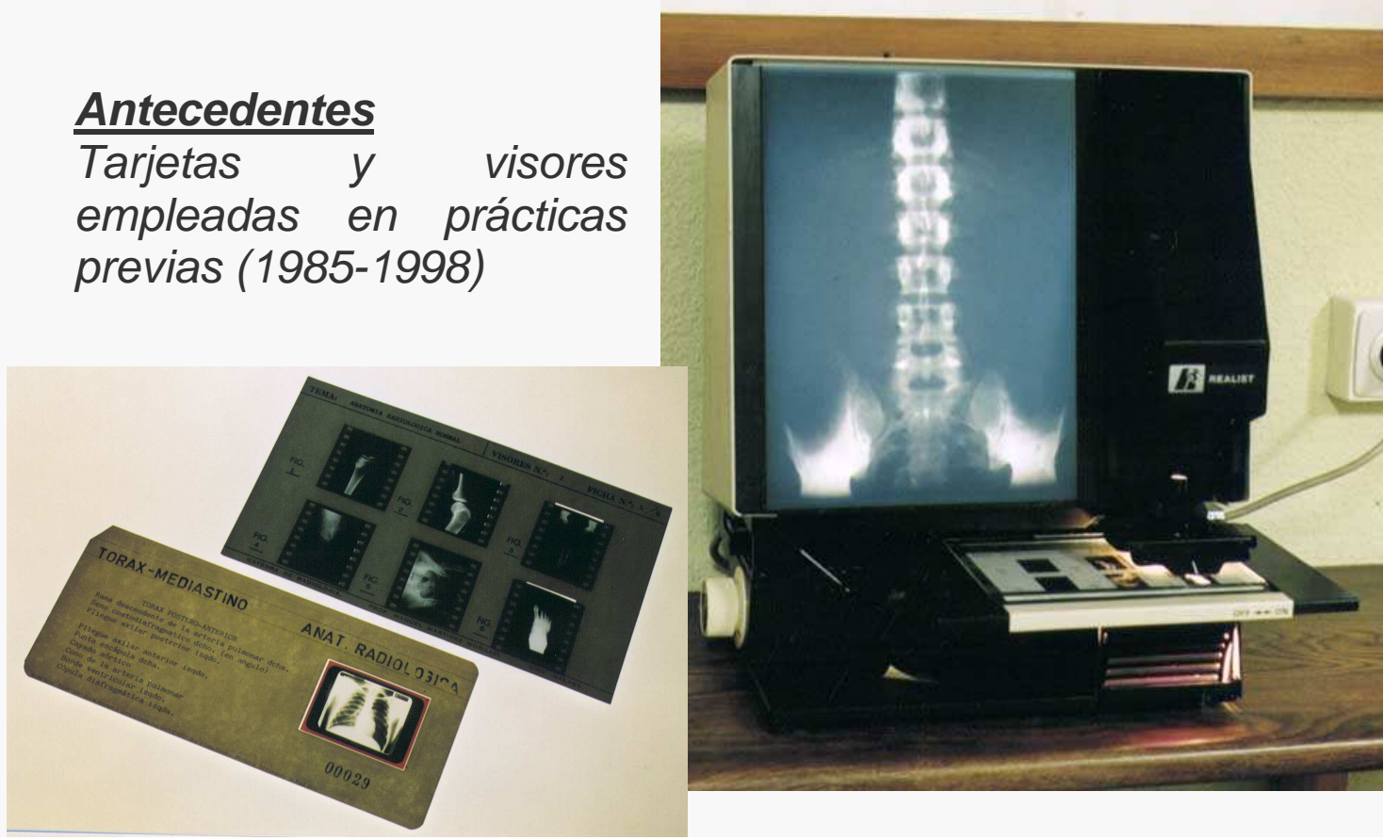

Figura 1.- Antecedentes de las prácticas asistidas por ordenador "Un Paseo por la Radiología" realizadas con diapositivas y visores.

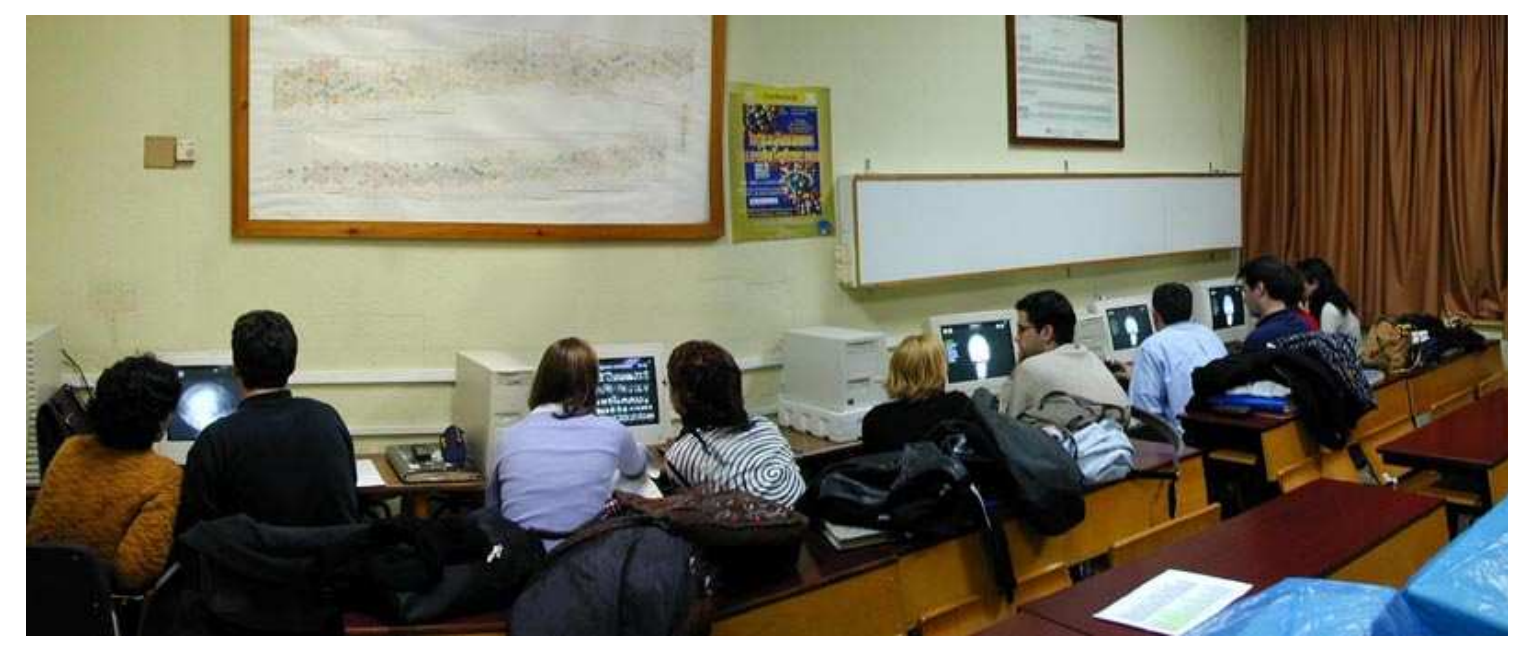

Figura 2.- Alumnos trabajando en el aula de prácticas con las primeras versiones de la aplicación "Un Paseo por la Radiología".

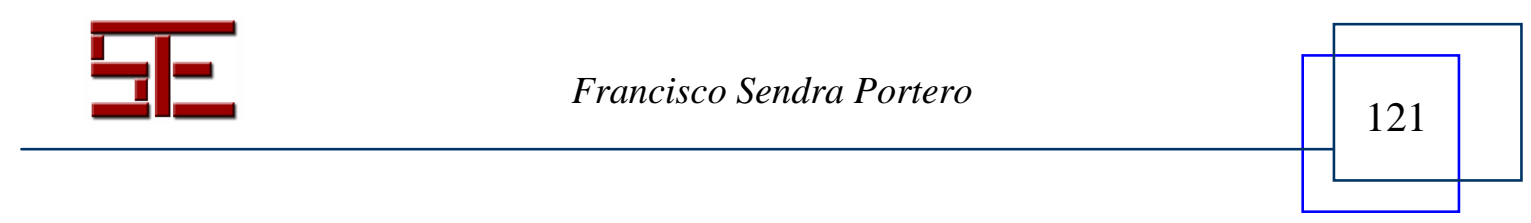




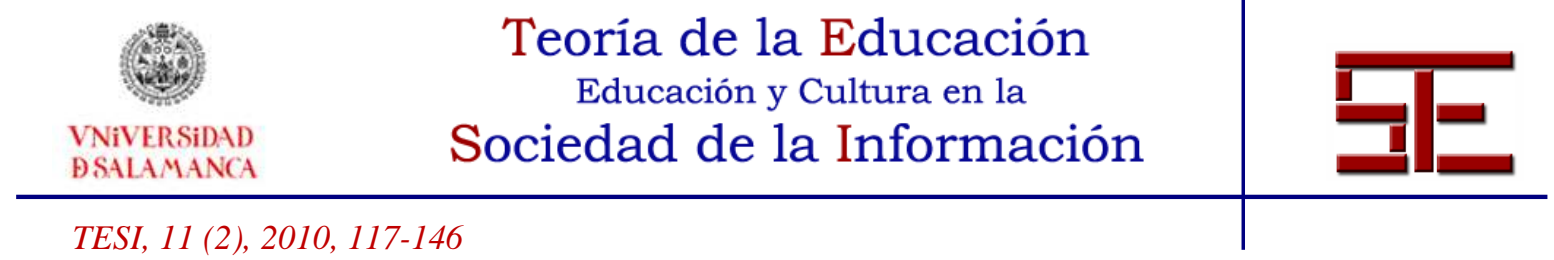

Un Paseo por la Radiología es una colección de casos variada, en la que el usuario puede visitar las imágenes tranquilamente, como dando un paseo, de ahí su nombre. El alumno puede ir descubriendo a su propio ritmo que tipo de hallazgos le resultan más difíciles de identificar y que problemas encuentra en la relación entre percepción visual y conocimientos teóricos. La práctica contiene 72 casos normales y 75 patológicos en dos colecciones. En cada colección se puede realizar toda la práctica de un extremo a otro, caso a caso, mediante avance y retroceso, o selectivamente, desde las páginas centrales tipo 'home page' de imágenes normales o patológicas.

En la figura 3, se presentan varias capturas de pantalla de un Paseo Por la Radiología, con una pantalla principal con iconos entre los que se puede elegir uno de los 6 idiomas en que está traducida la versión actual, 3.1. En el lado superior derecho de la imagen se muestra el menú principal en español, desde el cual se puede optar por acceder a las imágenes normales o patológicas, créditos, objetivos, ayuda o al menú de idiomas. Las dos imágenes de abajo corresponden a los menús de acceso a cada caso en las colecciones de imágenes normales y patológicas. Al pulsar sobre cada imagen se accede al caso correspondiente.
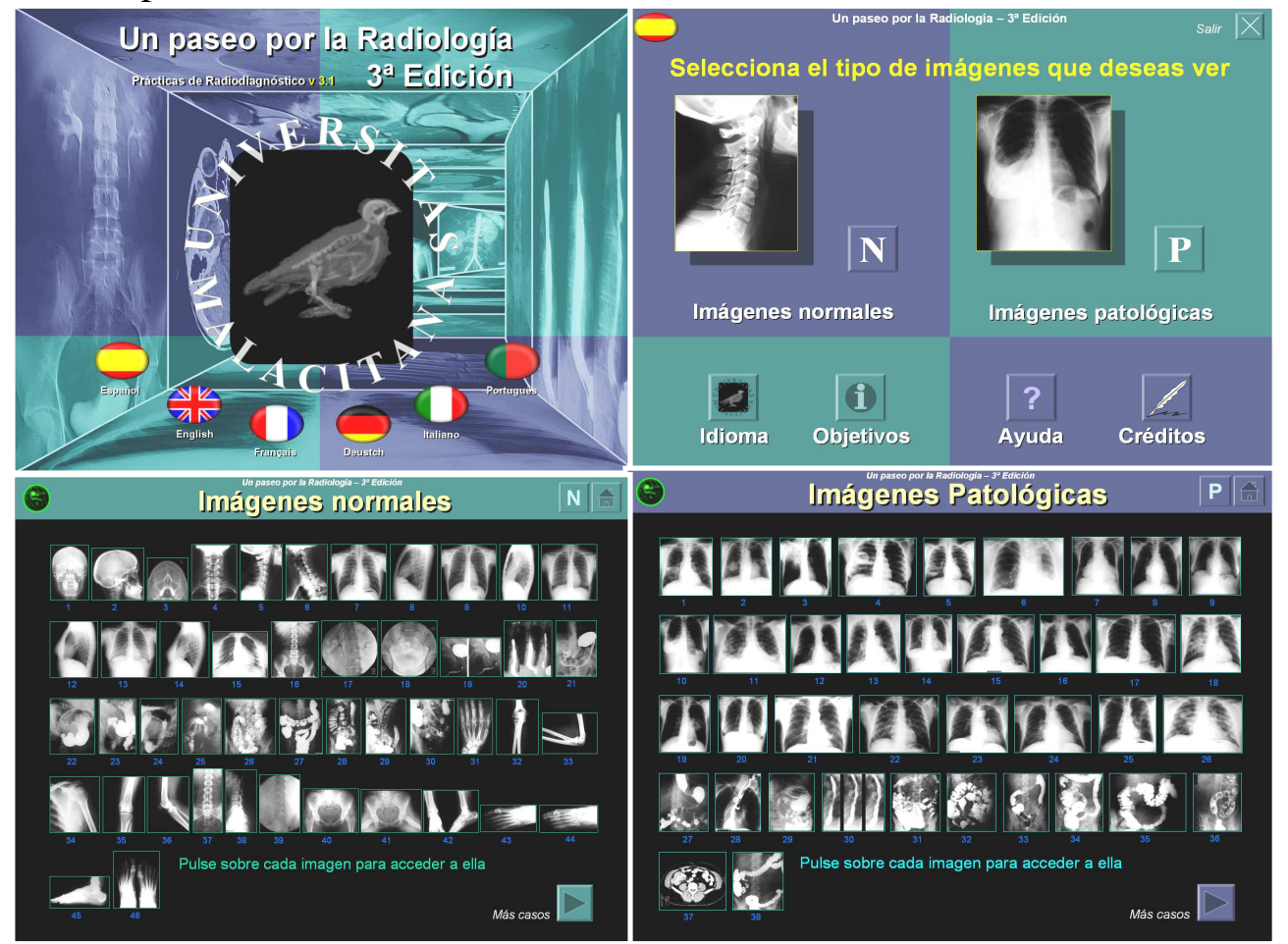

Figura 3.- Se presentan cuatro capturas de pantalla de la $3^{a}$ edición de un Paseo por la Radiología®: Pantalla principal de distribución de idiomas, selección de opciones en español y páginas principales de imágenes normales y patológicas.

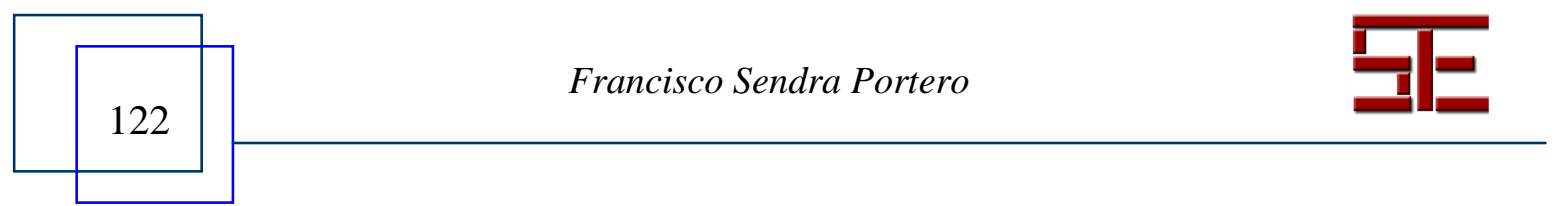




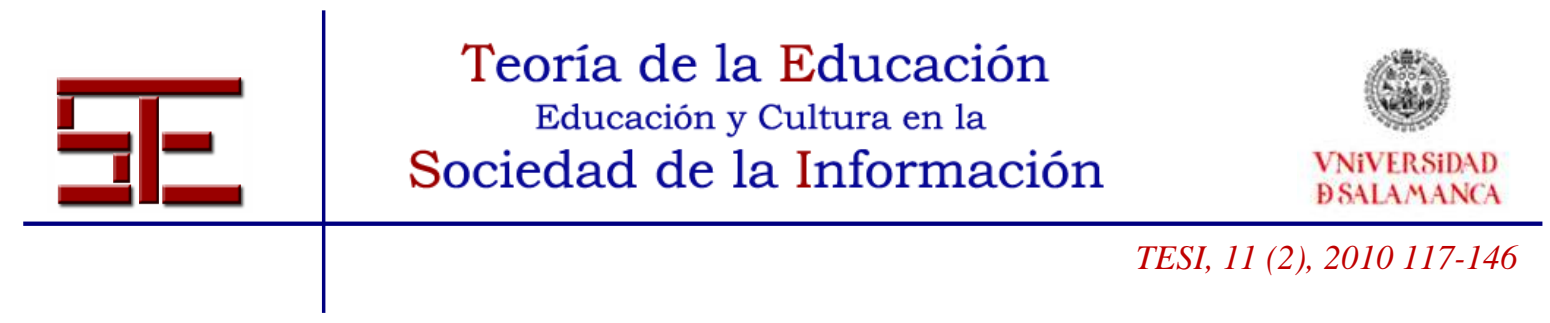

En la figura 4 se muestran dos capturas de pantalla de la aplicación correspondientes a un caso normal, en el que se pide al alumno que identifique una serie de estructuras. Al pulsar el botón con el signo de interrogación, el alumno encontrará la respuesta correcta. Las flechas de avance o retroceso conducen a los casos anteriores o siguientes.

En las imágenes patológicas el funcionamiento es similar. Se presenta una pantalla de preguntas, ante el la cual el alumno debe evaluar la imagen mostrada, reconocer las anomalías posibles, sus características, e intentar decidir sobre su correlación con la causa más probable. Al presionar sobre el botón de interrogación, obtendrá las respuestas correspondientes (Fig. 5), que aparecen marcando o delineando cada uno de los elementos de manera sucesiva, para que el alumno tenga tiempo de asimilar el contenido.

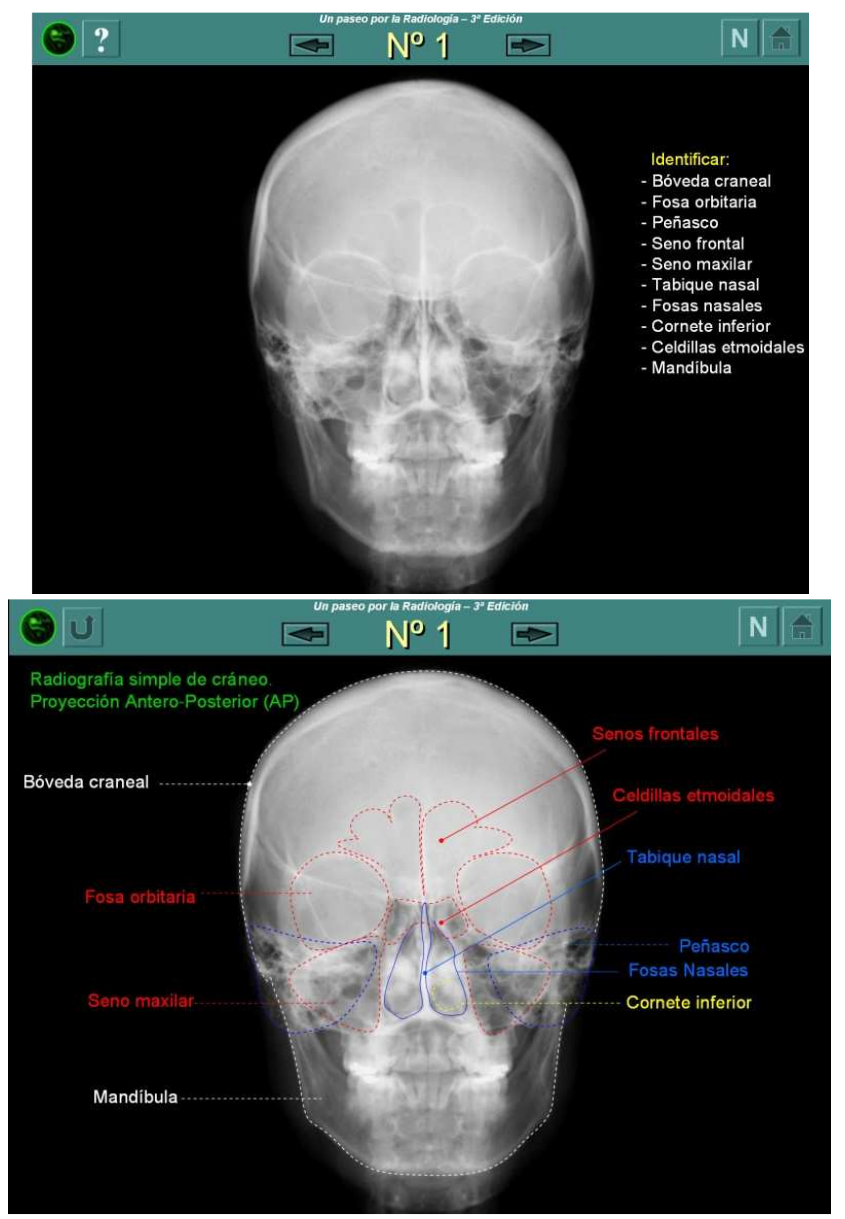

Figura.4. Capturas de pantalla de un caso correspondiente a imágenes normales. La presentación inicial (arriba) presenta una lista de los hallazgos anatómicos que se deben identificar. Una vez pulsado el botón de respuesta se muestran éstos debidamente señalados.

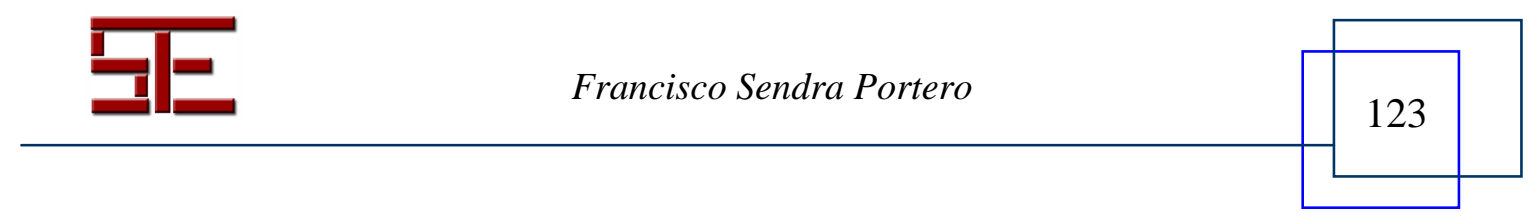



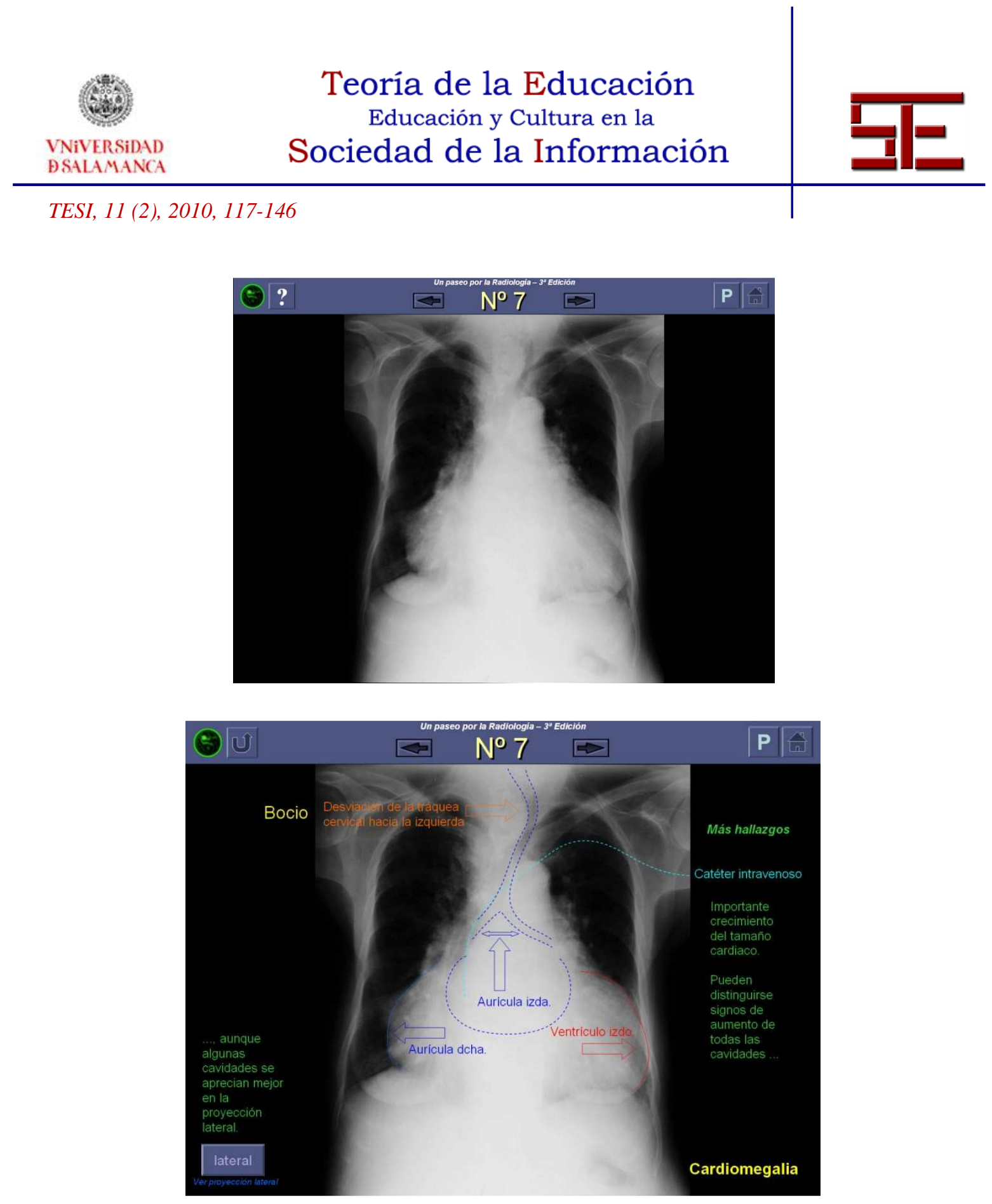

Figura.5. Capturas de pantalla de un caso correspondiente a imágenes patológicas. La presentación inicial (arriba) se muestra sin información adicional alguna, salvo la imagen. El alumno debe identificar y pensar en la descripción de hallazgos antes de pulsar el botón de respuesta y acceder a la pantalla de respuesta (abajo), en la que van apareciendo mediante transiciones sucesivas la información correspondiente, tanto del hallazgo fundamental, la cardiomegalia en este caso, como de los accesorios (bocio, catéter intravenoso).

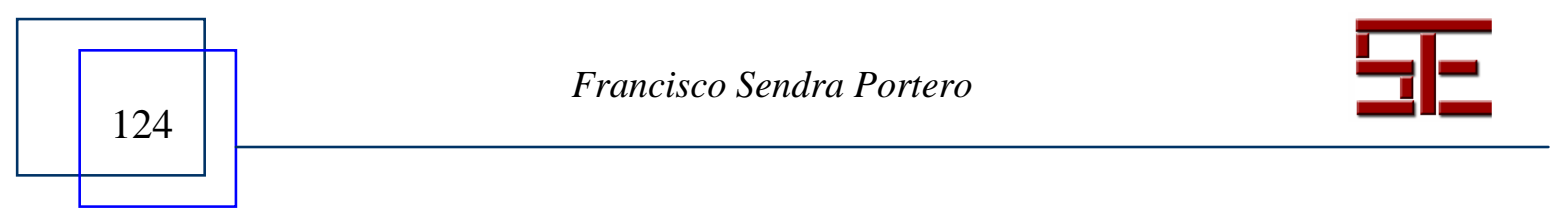




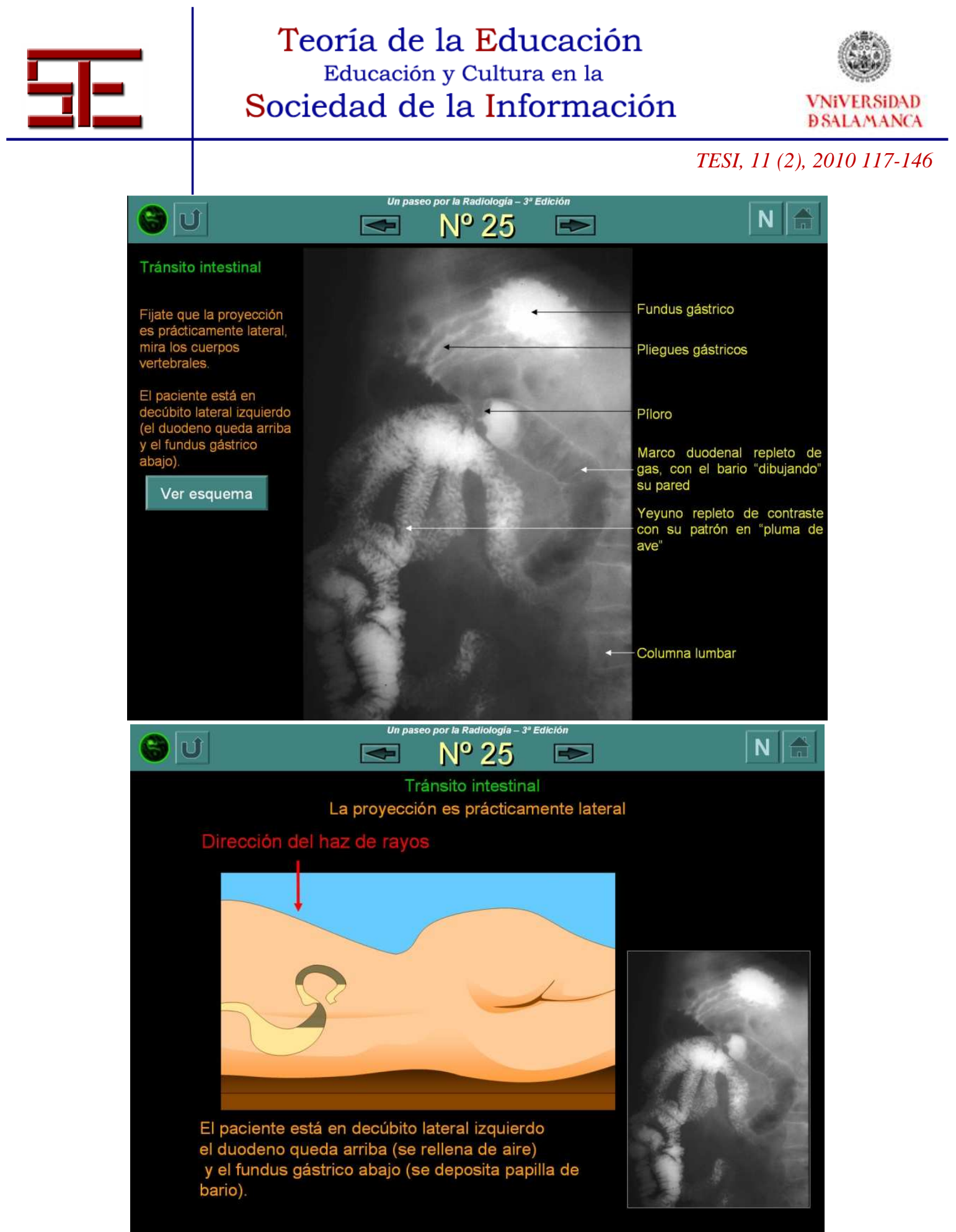

Figura 6. Capturas de pantalla de un caso correspondiente a imágenes normales en el que se presenta un esquema explicativo adicional para comprender porque el aire y el contraste se ven de una determinada manera en una posición concreta.

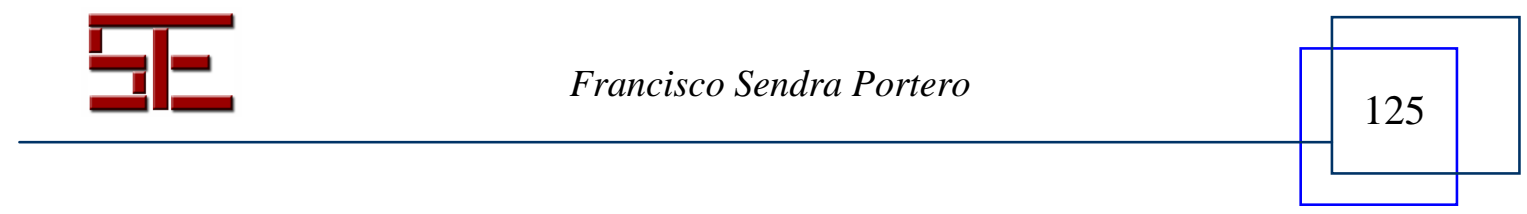




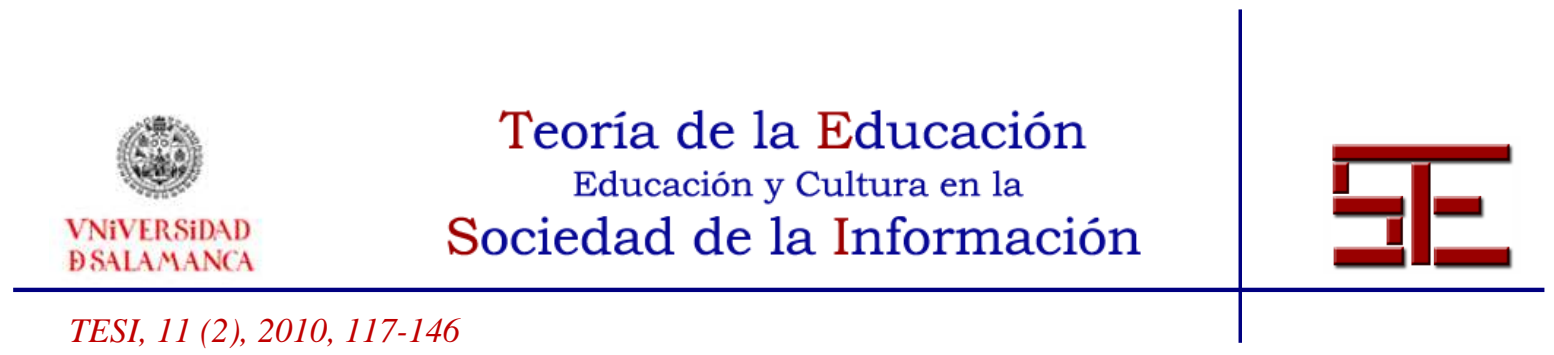

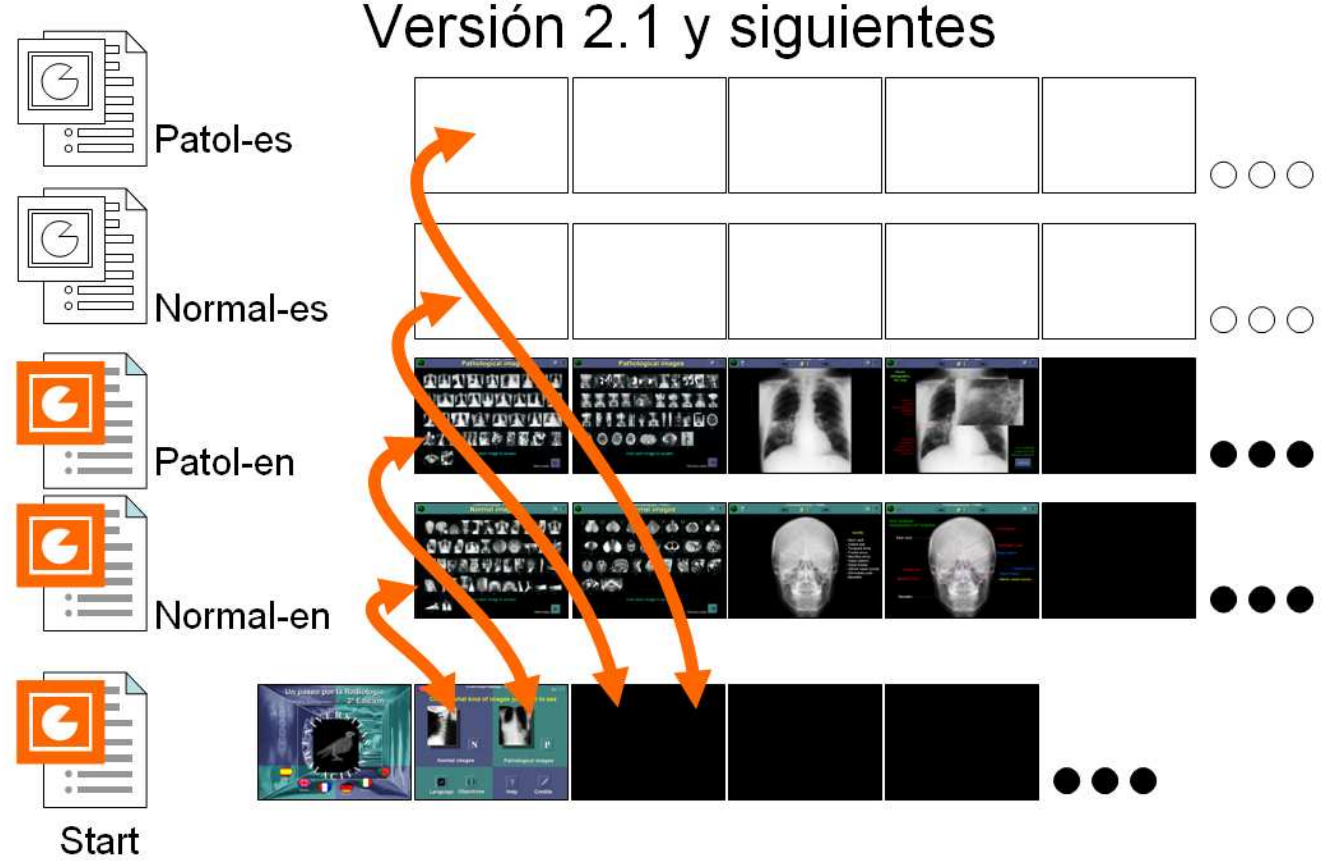

Figura 7. Esquema de la estructura de presentaciones PowerPoint enlazadas de Un Paseo por la Radiología. El usuario navega a la presentación normal o patológica en el idioma seleccionado y puede regresar a la presentación de inicio subyacente.

En algunos casos, se da la opción a acceder a esquemas explicativos sobre la técnica o sobre el caso práctico. En la figura 6 se muestra un ejemplo que presenta de forma más comprensible la incidencia del haz de rayos para obtener la imagen radiográfica.

Un Paseo por la Radiología está organizado como un conjunto de presentaciones PowerPoint enlazadas, de manera que hay una presentación de inicio con los menús de distribución que conducen a otras presentaciones con la serie normal o patológica en los diferentes idiomas en los que está traducida la aplicación. El esquema de distribución está representado en la figura 7.

El proyecto ha evolucionado desde que se presentó el prototipo, que corresponde a la versión 1.0, en1998. A partir de ahí, se han mejorando las imágenes, se han agregado nuevas, se ha optimizado la adaptación a las presentaciones on-line, primero con versiones html traducidas directamente desde PowerPoint y recientemente convertidas a Flash para experimentar con estos nuevos formatos diseñados para presentación on-line.

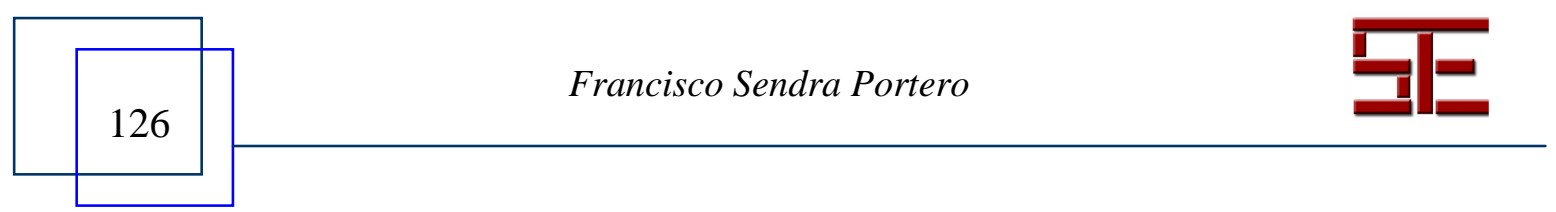




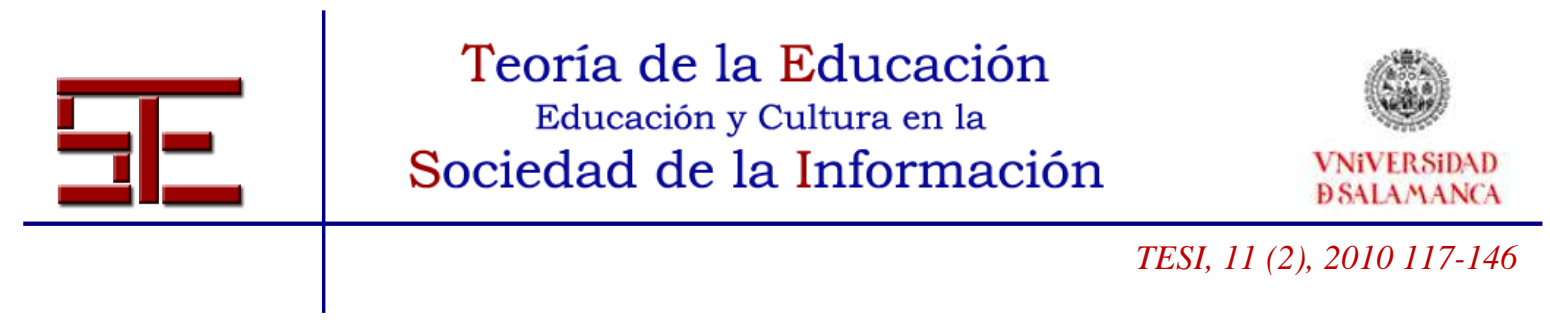

La información proporcionada por los alumnos ha sido muy importante para realizar modificaciones y mejoras paulatinas. Se han editado dos CD-ROM con las versiones 1 y 2 del proyecto (Martínez Morillo y Sendra Portero, 2000, 2002) y actualmente está pendiente la edición de un tercer CDROM con la $3^{\text {a }}$ versión, traducida a 6 idiomas. La evolución de Un Paseo por la Radiología, se resume como sigue:

- Oct 1998 Prototipo versión 1.0

- Ene 2000 Edición versión 1.1 (CD-ROM)

- Feb 2000 Edición versión 1.1 html (on-line)

- Ene 2001 Modificación enlaces y funcionalidad versión 1.2. Edición on-line

- Ago 2001 Comienza trabajo de la versión 2.0

- Dic 2002 Edición versión 2.1 (CD-ROM) trilingüe (Esp-Ing-Fra)

- Feb2003 Edición versión 2.1 html (on-line)

- Sep 2005 Comienza trabajo versión 3.0

- Sep 2006 Finalizada versión 3.16 idiomas (Esp-Ing-Fra-Ale-Ita-Por)

- Ene2007 Versión 3.1 on-line (flash)

- Jun 2008 Comienza trabjo version 3.2 (optimización de imágenes)

- Dic 2009 Pendiente edición CD-ROM

\section{3.- MATERIAL DE CONSULTA}

Las aplicaciones multimedia pueden proporcionar excelentes herramientas de consulta que permiten estudiar temas organizados por capítulos o bien repasar aspectos concretos facilmente, gracias a la flexibilidad que ofrece la navegación orientada a objetos. En nuestro departamento se han desarrollado algunos proyectos de este tipo que se describen a continuación.

\section{1.- El proyecto AULAGA}

Es una aplicación multimedia para la docencia de la TC de tórax, diseñada originalmente para residentes de Radiología. Explica y desarrolla conceptos sobre técnica, anatomía y cáncer de pulmón, empleando texto, gráficos, dibujos, imágenes radiológicas, sonidos y videos (Fig. 8). Fue diseñada por el Dr. Algarra constituyendo su Tesis Doctoral en el año 1998 (Algarra García, 1998).

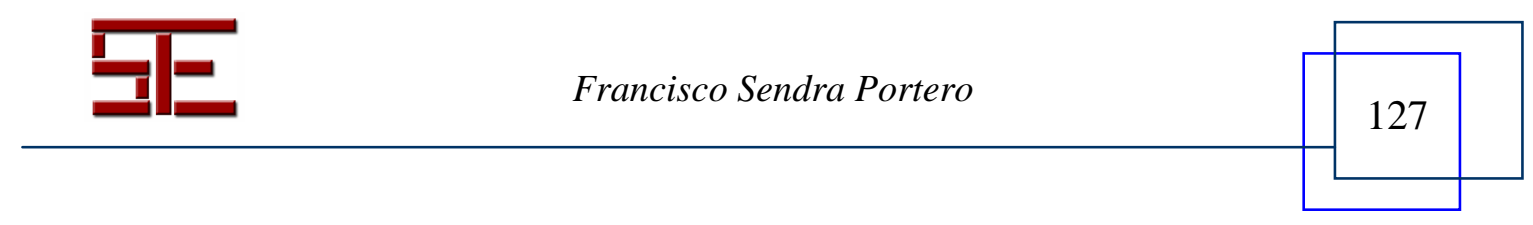




\begin{tabular}{c} 
Teoría de la Educación \\
Educación y Cultura en la \\
$\begin{array}{c}\text { VNiVERSIDAD } \\
\text { DSALAMANCA }\end{array}$ \\
\hline$T E S I, 11(2), 2010,117-146$
\end{tabular}
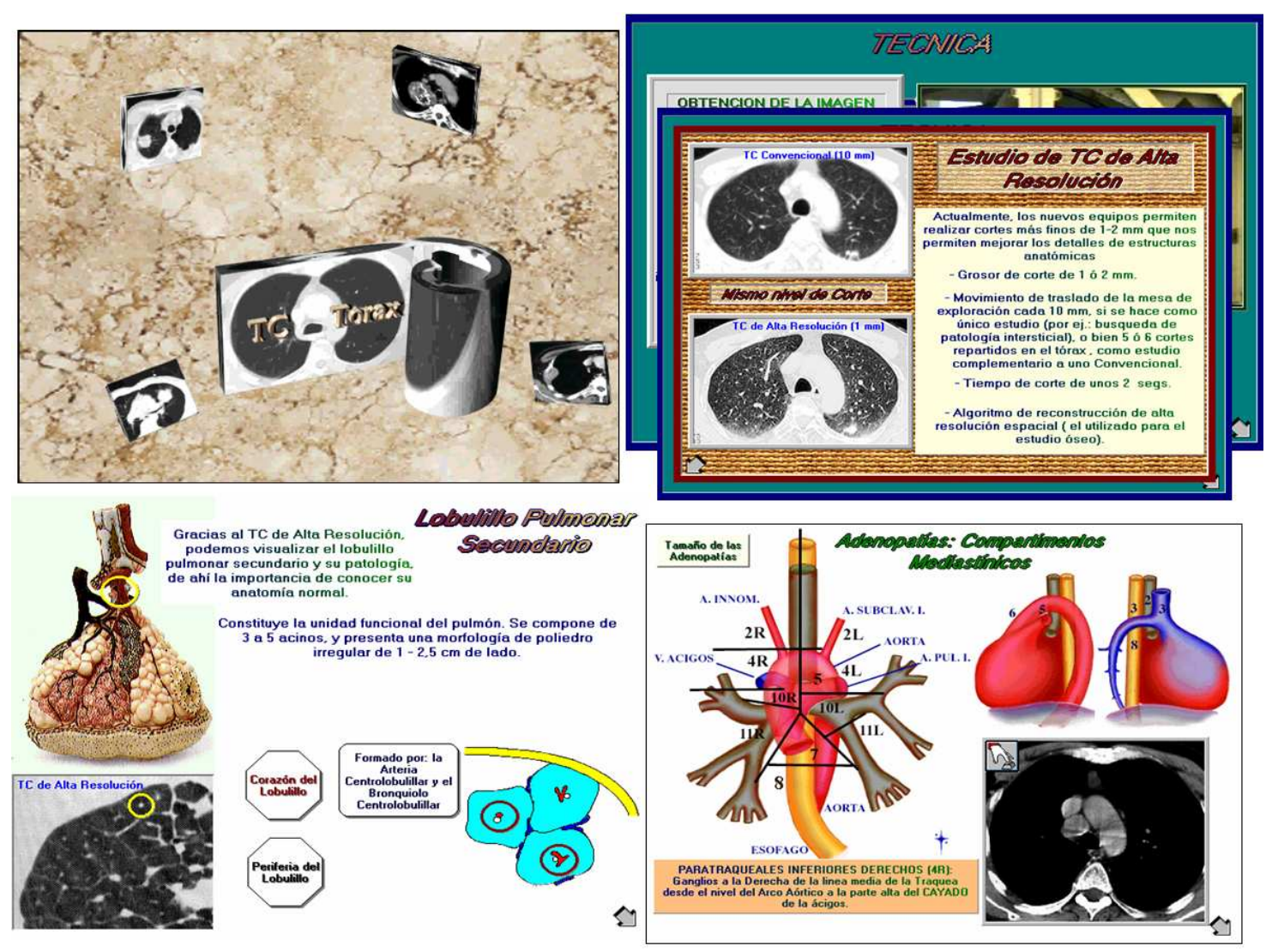

Figura 8. Capturas de pantalla de la versión original del proyecto aulaga: presentación de la aplicación, anatomía, técnica y cáncer de pulmón. 


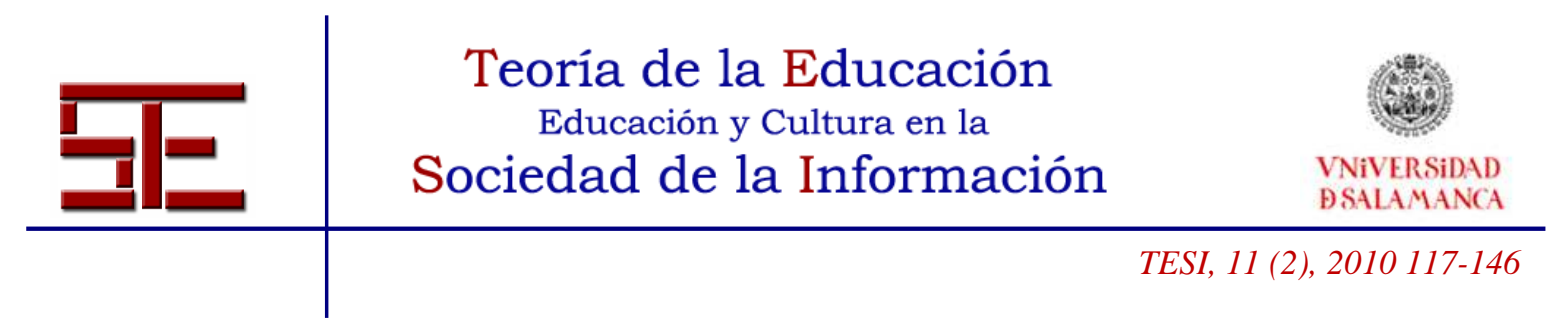

El proyecto Aulaga (1998)

Residentes: porcentaje de aciertos antes y después de usar la aplicación

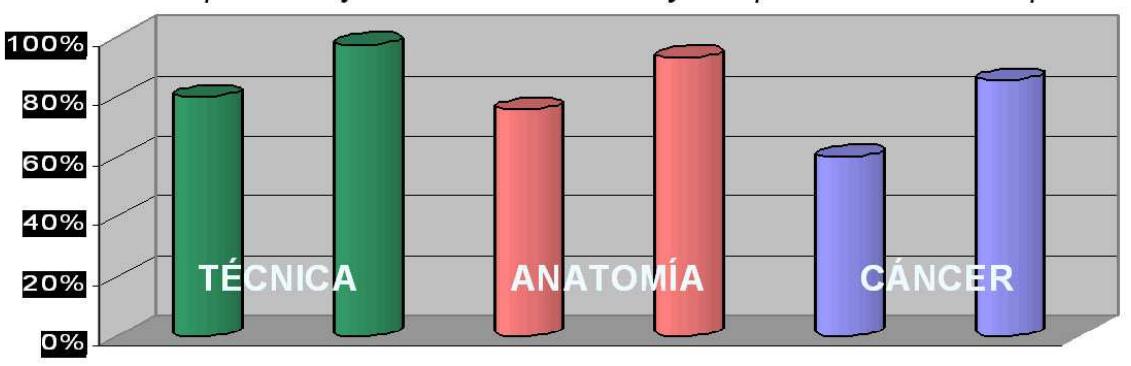

Estudiantes: porcentaje de aciertos antes y después de usar la aplicación

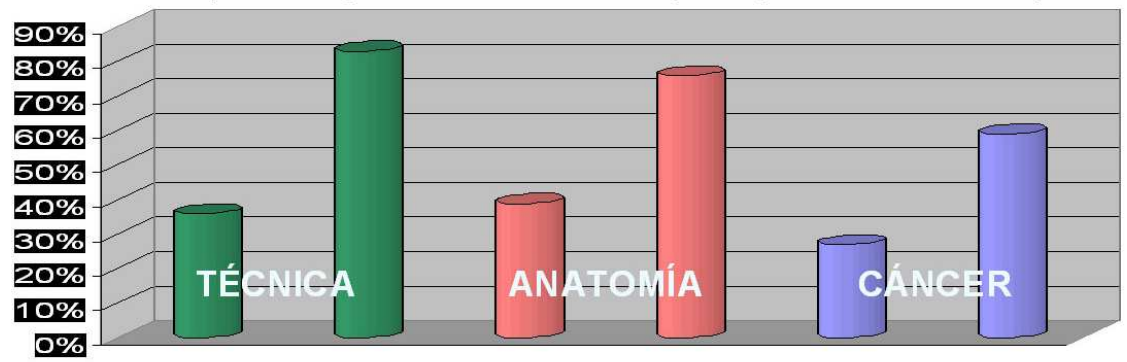

Figura 9. Encuestas antes (izquierda) y después (derecha) de utilizar el programa AULAGA, sobre técnica (verde), anatomía torácica (rojo) y cáncer de pulmón (violeta), realizadas a residentes y estudiantes de medicina.

La aplicación, programada originalmente en VisualBasic $\AA$, fue reeditada implementando sus contenidos en PowerPoint. Actualmente se puede encontrar información sobre este proyecto en http://www.ieev.uma.es/radiolog/AULAGA.htm. Los avances técnicos en radiología han dado lugar a que la tecnología e imágenes empleadas en este proyecto resulten un tanto obsoletas actualmente. Por este motivo se está estudiando planificar una versión 4.x más completa y actualizada.

Como parte del proyecto inicial, se realizó una evaluación de usuarios que refleja algunos resultados muy interesantes. Participaron residentes de Radiología y Neumología antes y después de emplear la aplicación, así como alumnos de sexto curso de medicina. El trabajo demostró que una aplicación diseñada para residentes utilizada por alumnos de medicina, conduce a notables mejoras en los conocimientos adquiridos por los estudiantes, teniendo en cuenta obviamente que la tasa de aciertos es inferior a la de los residentes (Fig. 9). La conclusión evidente es que los recursos diseñados para postgrado (residentes) se pueden adaptar y utilizar en el pregrado de medicina con buenos resultados (Algarra García y cols., 1999).

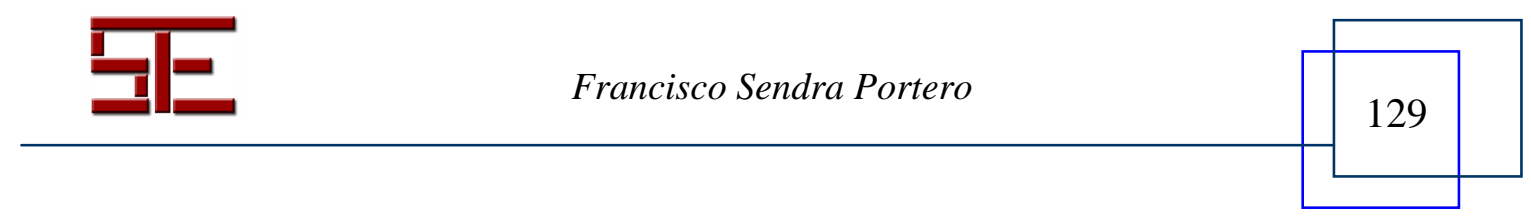




\begin{tabular}{c} 
Teoria de la Educación \\
Educación y Cultura en la \\
$\begin{array}{c}\text { VNiVERSADAD } \\
\text { DSALAMANCA }\end{array}$ \\
\hline TESI, $11(2), 2010,117-146$
\end{tabular}

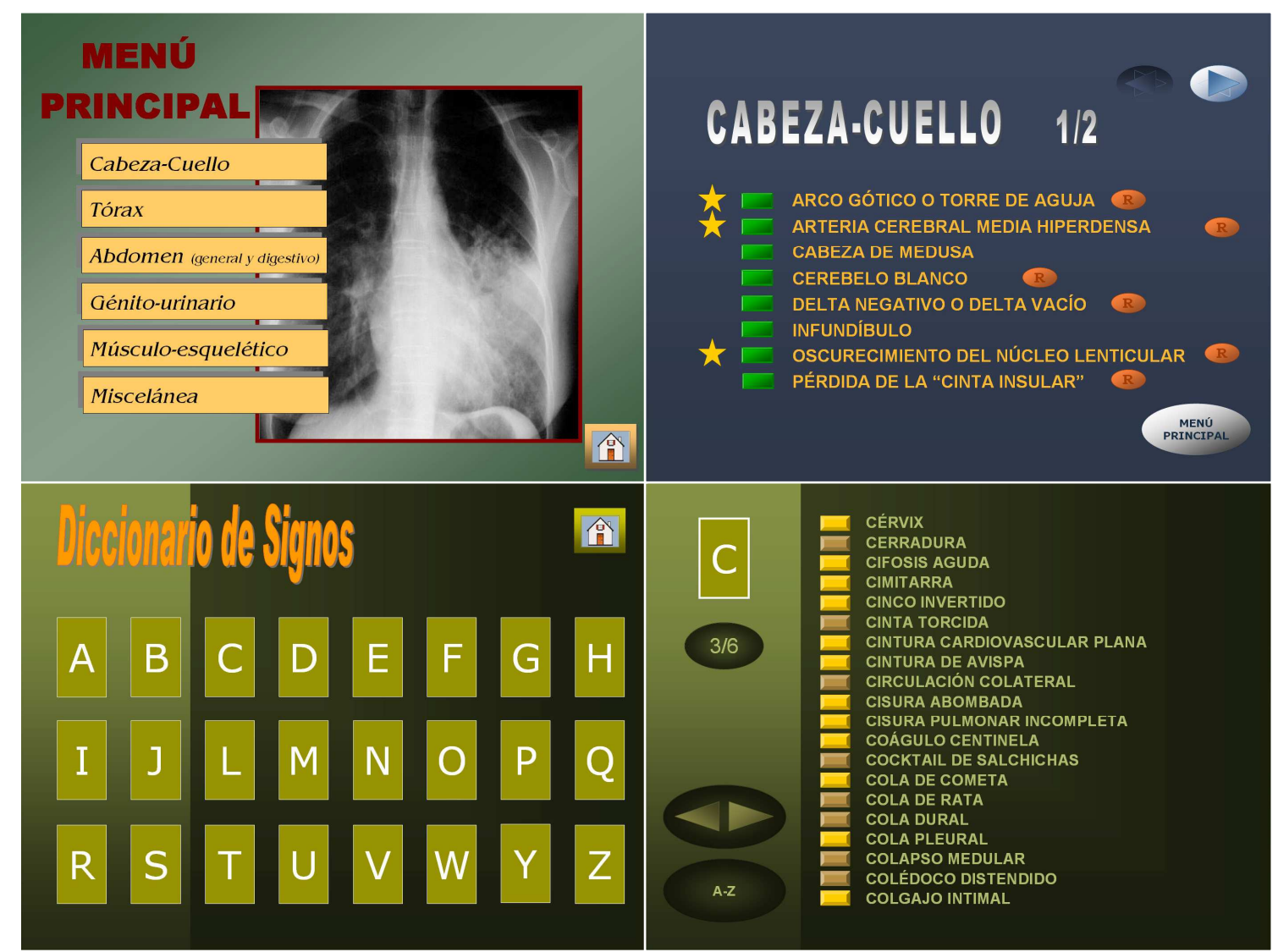

Figura 10. Capturas de pantalla de los menús de acceso a contenidos disponibles en la aplicación Álbum de Signos Radiológicos.

\section{2.- Álbum de Signos Radiológicos}

Es un trabajo multimedia que recoge una amplia colección de semiología radiológica con fines docentes. Incluye un diccionario con más de 800 registros y un álbum con imágenes de 356 signos. Está destinado tanto a estudiantes de medicina como a residentes y radiólogos, estructurado en unos 400 archivos PowerPoint vinculados entre si. La versión 2.1 se editó en CD-ROM en 2006 (Navarro Sanchos y Sendra Portero, 2006). Actualmente está agotada y se está trabajando en el desarrollo de la versión 3.0.

En la figura 10 se presentan varias capturas de pantalla de esta aplicación que muestran como acceder a los signos radiológicos. Un menú principal conduce a distintas áreas anatómicas, desde donde se puede acceder a cada signo. Algunos signos están acompañados de una estrella amarilla, que los identifica como signo básico, de interés

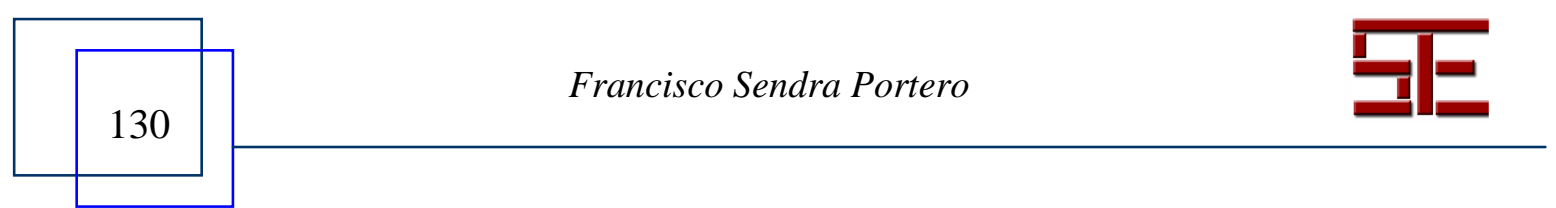




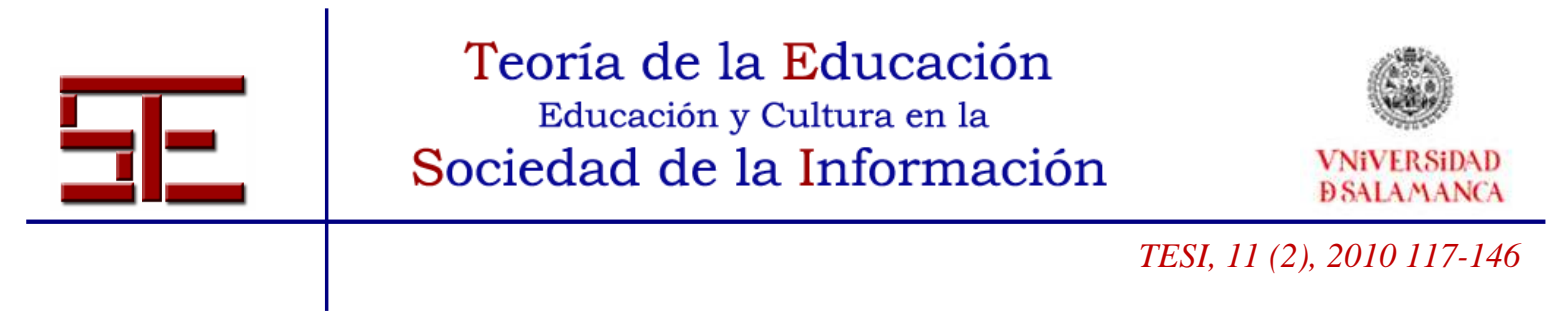

para estudiantes. También se acompañan opcionalmente de enlaces con otros signos relacionados, por el nombre o por la patología, a los que se accede mediante el icono ovalado color naranja con una "R" en su interior. La aplicación permite además acceder a los distintos signos mediante un diccionario interactivo con 800 signos radiológicos enumerados y casi 400 de ellos directamente accesibles desde este diccionario.

La figura 11 muestra otras cuatro capturas de pantalla de la aplicación con un ejemplo característico de como se presenta en el monitor cada signo radiológico. Desde una botonera a la derecha, donde está la imagen de inicio, se accede la exploración a la que corresponde este caso, a la leyenda que indica en que consiste exactamente el signo radiológico, a imágenes adicionales que se presentan para terminar de explicar dicho signo, y a la bibliografía, donde se describe el signo y donde el usuario puede remitirse si quiere saber algo más del mismo (autor, condiciones en que fue descrito, etc). El enlace a la Web con contenidos sobre este proyecto, es el siguiente:

http://www-rayos.medicina.uma.es/eao/AlbumSR.htm

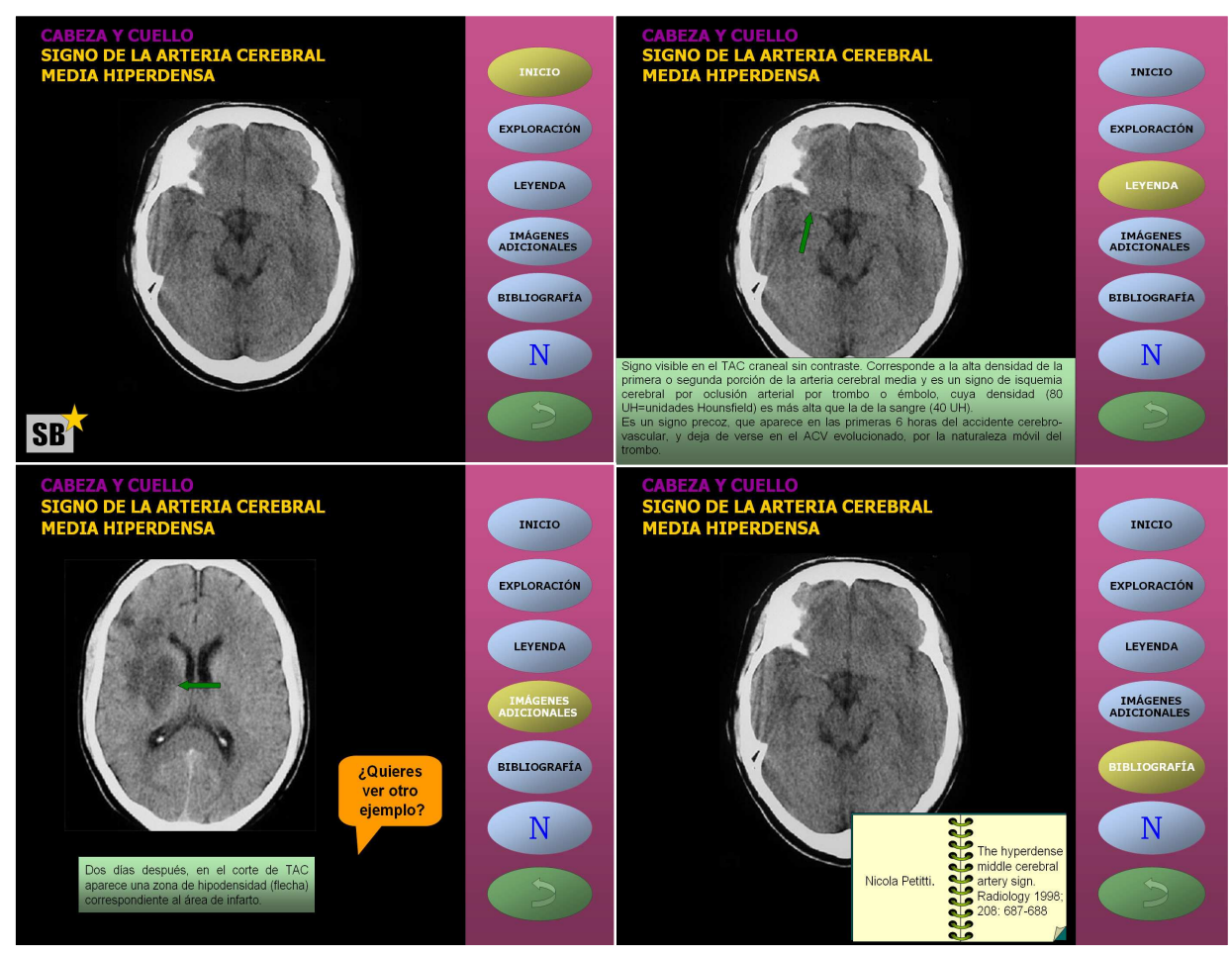

Figura. 11. Capturas de pantalla de un signo radiológico, en la que se muestra el inicio, la leyenda que se aporta, las imágenes adicionales y la bibliografía.

\subsection{TRIPA-TC. Tutorial de radiología, imágenes de pelvis y abdomen.}

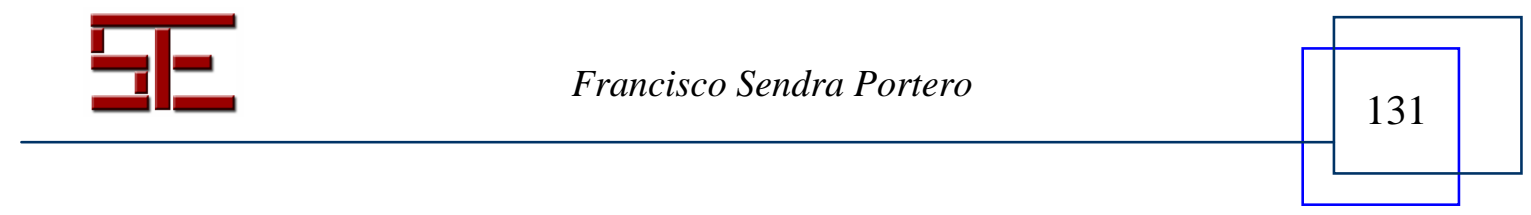




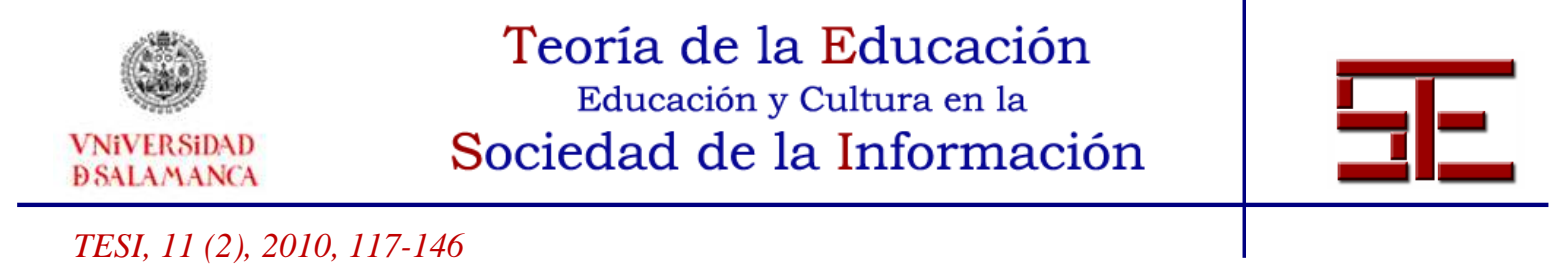

TRIPA-TC es una aplicación multimedia para la docencia de la TC abdominopélvica. Está claramente inspirada en el proyecto AULAGA. En la actualidad se está desarrollando la versión 1.2, cuyos contenidos están organizados en tres secciones: anatomía, técnica y patología. El proyecto, con las correspondientes pruebas y evaluaciones de usuarios y expertos constituye el tema de una tesis doctoral en curso de realización, cuyos resultados previos han sido presentados en varios congresos. La aplicación tiene tres secciones:

- La sección de anatomía presenta cuatro ejemplos (dos hombres y dos mujeres) con imágenes etiquetadas, para comprobar la correlación anatómica y las variantes entre diferentes personas.

- La sección de patología está organizada en subsecciones: hígado, bazo, páncreas, suprarrenales, riñón, tracto gastrointestinal, peritoneo y mesenterio, retroperitoneo, pelvis y pared.

- La sección de técnica, explica contenidos relacionados con la obtención de imagen, reconstrucciones especiales y el empleo de contraste.

Se trata de un manual básico en el que predomina la presencia de mucha imagen y poco texto, de forma que se refuerce fundamentalmente el aprendizaje visual (Fig. 12). Está diseñado para el inicio de la rotación de los residentes de radiología por la sección de abdomen, pero tiene una indudable utilidad para residentes de otras especialidades y estudiantes de medicina, al constituir un atlas grafico con numerosos ejemplos carácterísticos. Es un conjunto de 19 presentaciones PowerPoint enlazadas, a las que se accede desde una presentación de inicio (Fig. 13). Contiene más de 900 pantallas con imágenes, que ocupan menos de $300 \mathrm{MB}$.

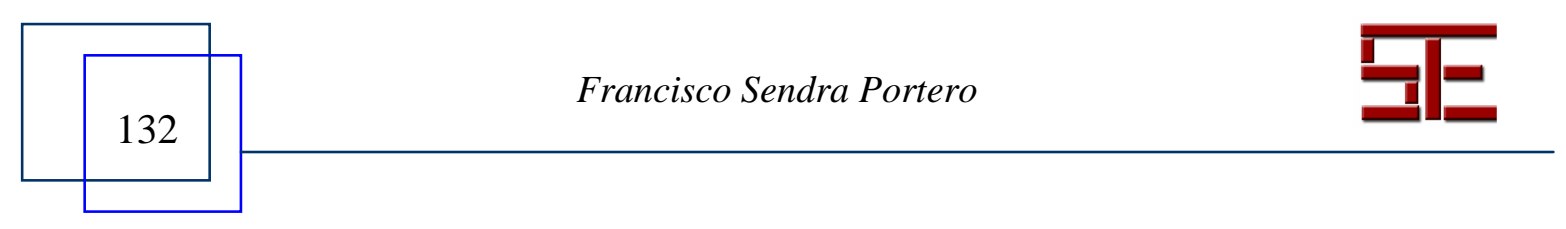



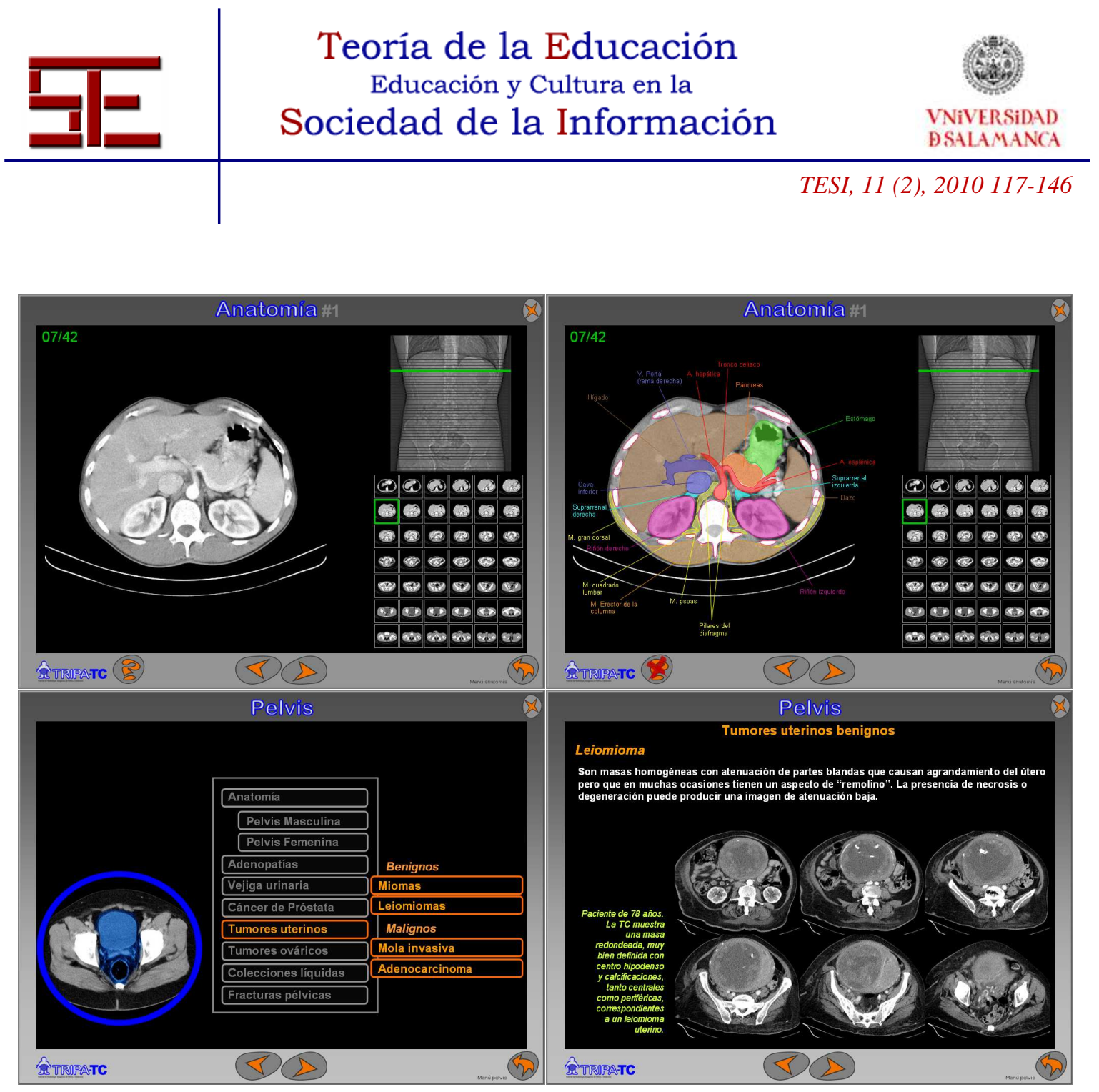

Figura 12. Captura de pantallas de la aplicación TRIPA-TC, correspondientes a la sección de anatomía (arriba). Pulsando el botón de interrogación se añaden o eliminan etiquetas identificativas de las estructuras anatómicas en colores semitransparentes. Los botones de avance y retroceso conducen al corte superior o inferior. Se muestran pantallas correspondientes a la sección de patología (abajo), con un menú interactivo para desplazarse rápidamente en el capítulo (izquierda) y un ejemplo de una pantalla con escaso texto e imágenes representativas.

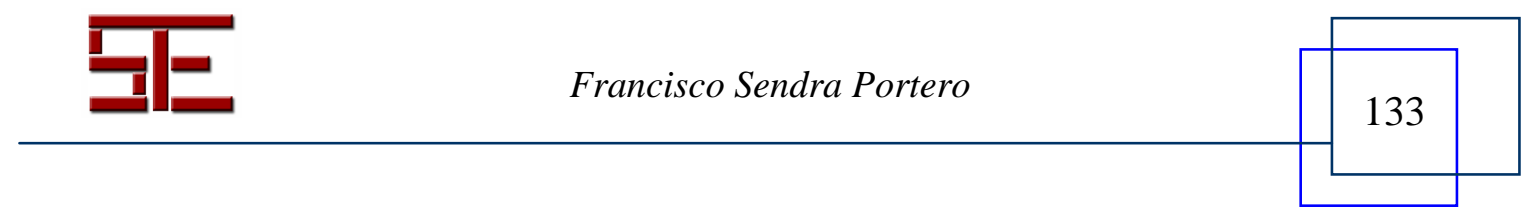




Teoría de la Educación
Educación y Cultura en la
$\begin{aligned} & \text { VNiVERSADAD } \\ & \text { BSALAMANCA }\end{aligned}$

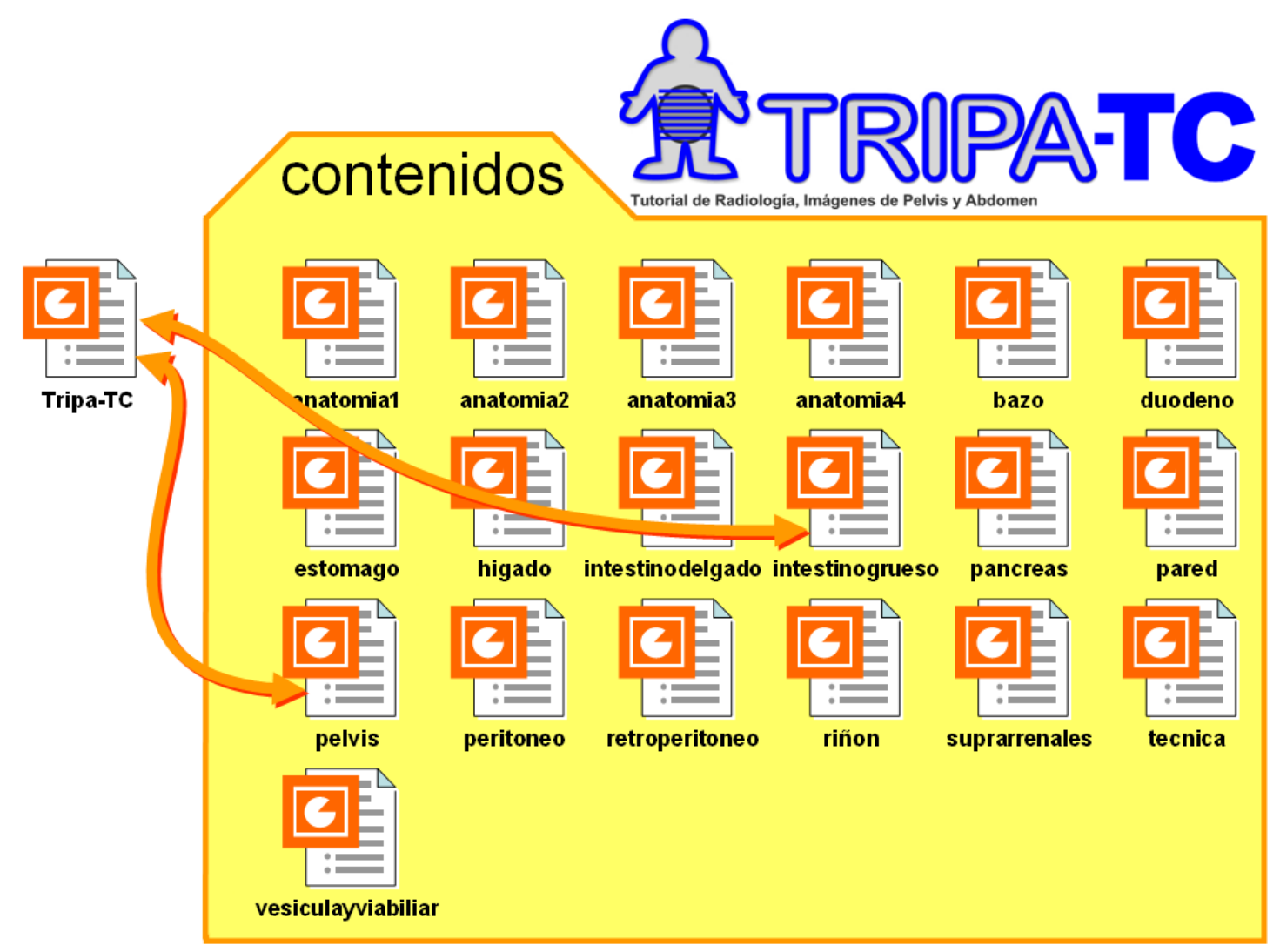

Figura 13. Esquema de la estructura de presentaciones PowerPoint enlazadas de TRIPA-TC. El usuario navega a los diferentes capítulos desde la presentación de inicio y puede regresar a ésta, que permanece abierta, subyacente en pantalla.

\section{4.- CLASES VIRTUALES. EL PROYECTO AMERAM.}

En ocasiones, las clases teóricas constituyen la única fuente de conocimientos que recibe el alumno en la enseñanza universitaria. Frecuentemente suponen una importante parte de la programación docente de la asignatura. El profesor bien expone un tema sobre el que ha adquirido cierta experiencia personal (lección magistral), o bien revisa y actualiza previamente a la clase, valorando y presentando aportaciones de otros autores. El profesor debe motivar al estudiante, sin limitarse a transmitir conocimientos, pero, lamentablemente, las clases teóricas suelen impartirse a un número excesivo de alumnos. La falta de participación activa de los estudiantes, que actúan como simples oyentes, y la escasa comunicación profesor-alumno son, en este escenario, dos grandes inconvenientes.

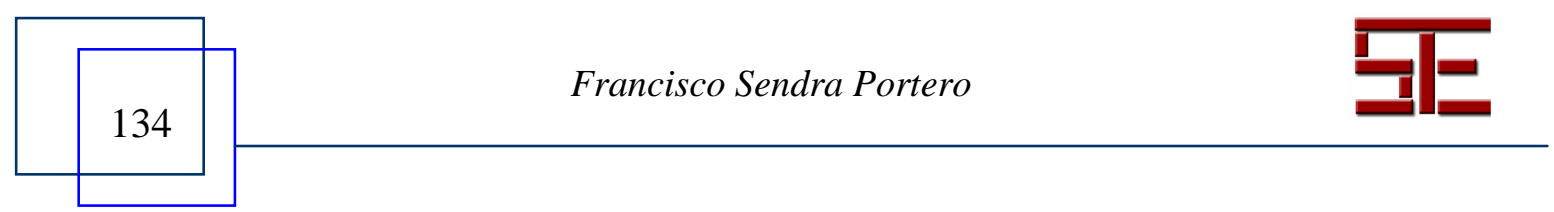




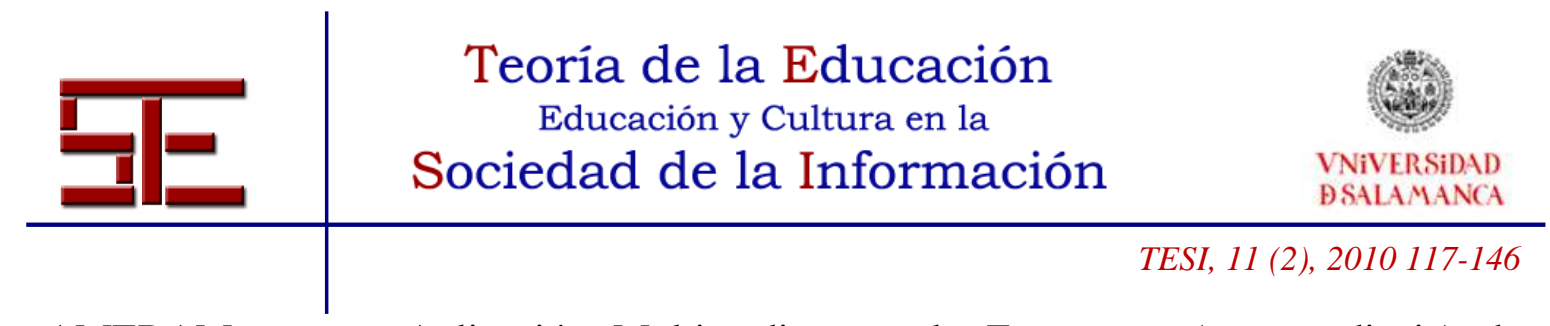

AMERAM es una Aplicación Multimedia para la Enseñanza (y aprendizaje) de Radiodiagnóstico a los Alumnos de Medicina, diseñada para un usuario específico, el estudiante de tercer curso de pregrado. El objetivo inicial de este proyecto es demostrar que la lección magistral puede sustituirse por lecciones virtuales, reservando el espacio y tiempo de la clase presencial para la discusión de contenidos, mediante los siguientes objetivos concretos:

- Crear una aplicación para la enseñanza/aprendizaje de Radiología basada en clases virtuales con acceso on-line.

- Realizar un proyecto piloto con alumnos de medicina para demostrar que las lecciones magistrales convencionales pueden sustituirse por lecciones virtuales sin perjuicio para el alumno.

- Demostrar que disponer de lecciones virtuales permite reutilizar el tiempo dedicado a clases teóricas con mayor aprovechamiento docente.

- Implantar en la enseñanza reglada de Radiología General, una asignatura troncal de tercer curso de la licenciatura de Medicina un recurso docente multimedia (AMERAM), basado en clases virtuales de acceso on-line.

- Difundir este recurso en otras universidades españolas e latinoamericanas.

Esta aplicación pretende cubrir una parte importante de los objetivos docentes de la asignatura "Radiología General", una asignatura troncal de tercer curso del plan de estudio de Licenciado en Medicina de la Universidad de Málaga que es uno de los pocos elementos comunes a la mayoría de planes de estudio de las universidades españolas (del Cura Rodríguez y cols., 2008), lo que hace el proyecto muy útil como material de apoyo al estudio en otras universidades. En el curso 2005-06 se inició un proyecto piloto en el que participaron voluntariamente alumnos de la asignatura Radiología General. Desde el curso 2006-07 AMERAM forma parte de la enseñanza teórica obligatoria de la asignatura.

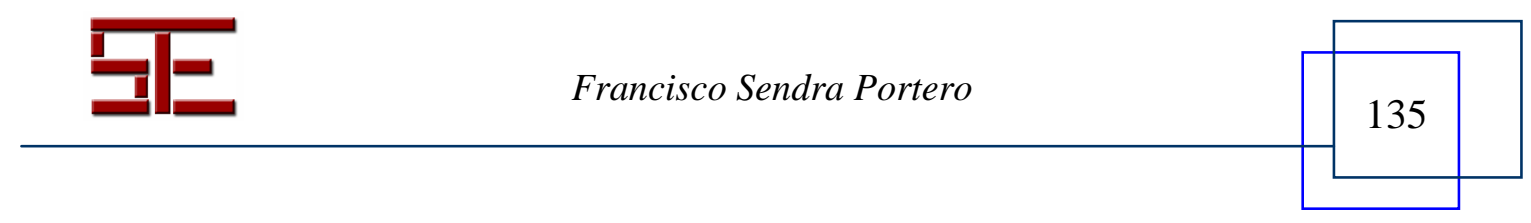




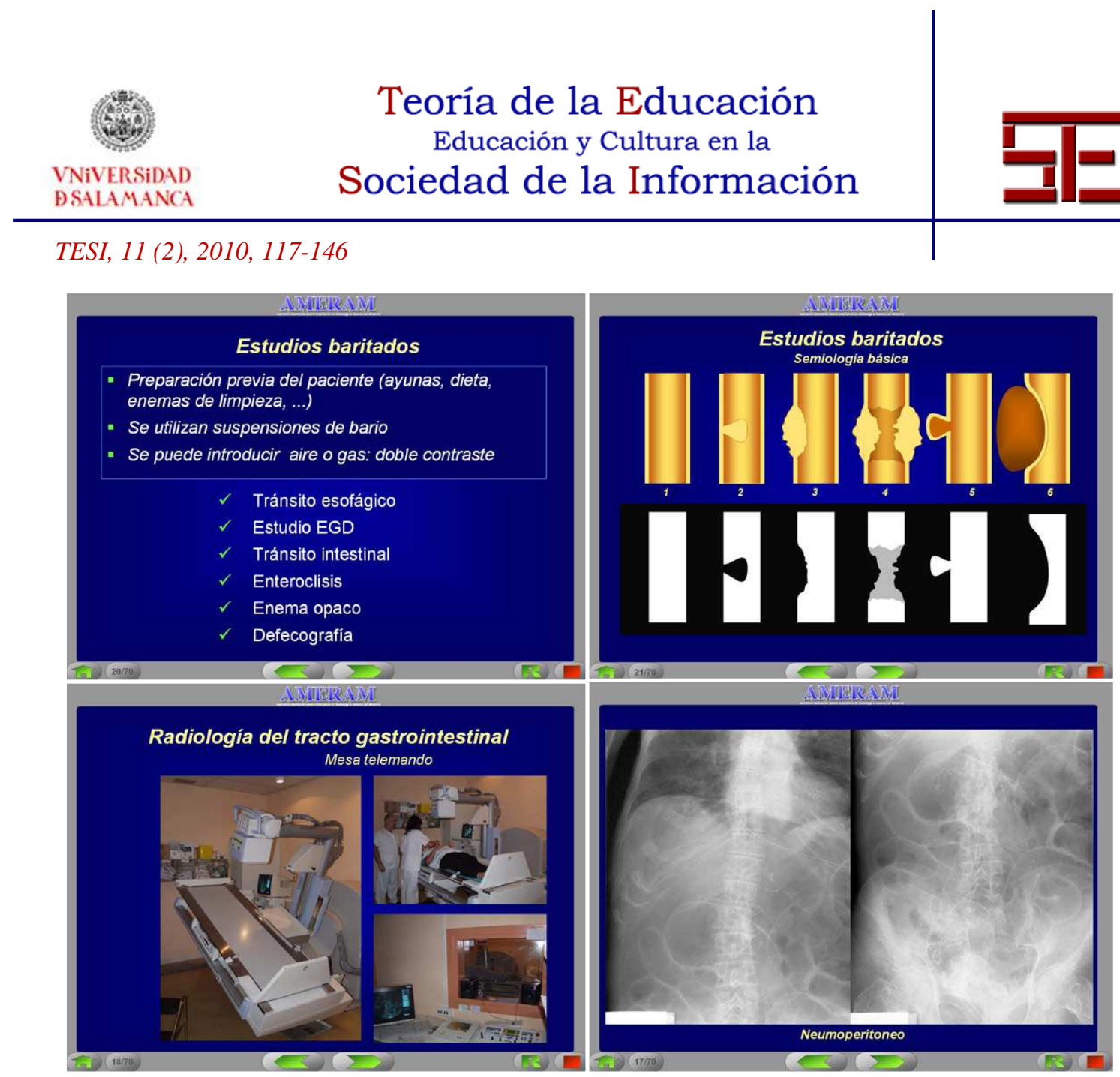

Figura 14. Capturas de pantalla de una de las clases virtuales con ejemplos de contenidos diversos: Textos, gráficos, fotografías y radiografías. En la barra inferior pueden apreciarse botones de vuelta al menú principal, avance, retroceso, repetir el audio o salir de la aplicación.

El contenido de las lecciones virtuales está construido mediante presentaciones Flash, traducidas a partir de presentaciones PowerPoint con audio, mediante PointeCast 4.3.1.192. La presentación tiene una interfaz homogénea y simple de utilizar, permitiendo avance, retroceso, ir al menú principal o incluso repetir la narración de cada diapositiva si se desea. Las fases de elaboración de cada una de las clases virtuales, han sido:

- Elaboración del fichero PowerPoint

- Grabación de audio

- Traducción de los contenidos a una presentación Flash

- Instalación de la presentación Flash en un servidor de Internet

AMERAM 1.0 está integrada por 22 presentaciones con narración en audio, estructuradas siguiendo el esquema de una clase convencional. Al principio de cada tema se presenta una sinopsis de lo que el usuario va a ver, con hipervínculos a las

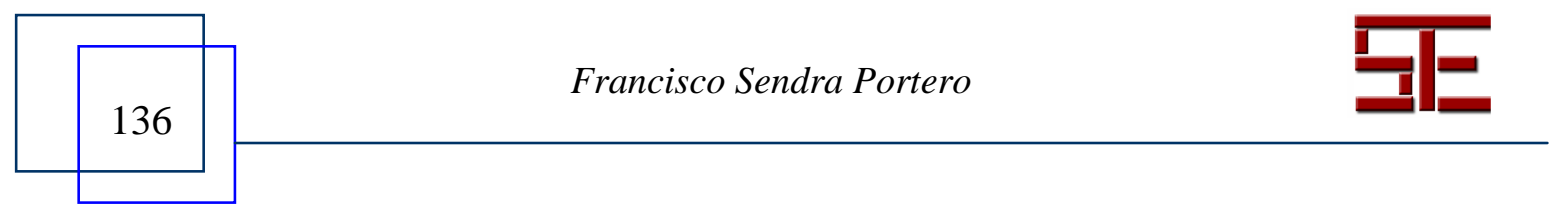




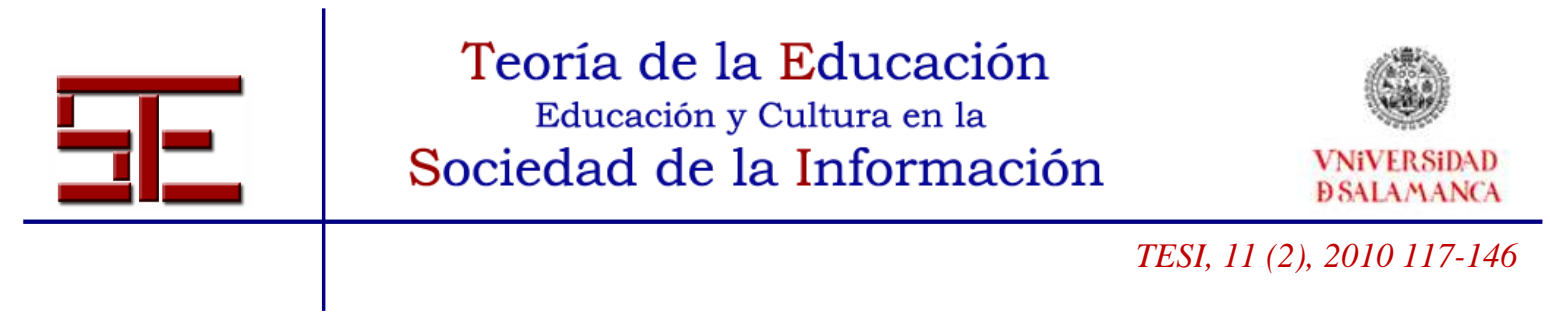

secciones del tema y es el propio usuario quién decide el ritmo con el que avanza a lo largo del tema. Componen la aplicación 6 capítulos de fundamentos técnicos y 16 capítulos organizados por aparatos y sistemas, en los que se tratan fundamentalmente tres aspectos: modalidades de estudio, interpretación de imágenes normales (anatomía radiológica), e identificación y descripción de imágenes patológicas elementales (semiología radiológica básica). Las carpetas de las 22 clases virtuales se instalaron en el servidor del campus virtual de la universidad de Málaga (plataforma antigua). Actualmente están alojadas en el servidor del Laboratorio de Radiología Digital y Enseñanza Electrónica y son accesibles desde el URL www.ameram.es.

\subsection{El proyecto piloto}

A principios del curso 2005-2006, se propuso a los alumnos crear un grupo de voluntarios, que estudiaran las lecciones teóricas incluidas en el proyecto exclusivamente mediante el acceso 'on-line' a las correspondientes clases virtuales, sin acudir a las clases presenciales. De 191 alumnos matriculados, participaron en el proyecto 89 alumnos $(46,6 \%)$. Los 102 restantes constituyeron el grupo control.

En el proyecto piloto se evaluaron los resultados de los exámenes ordinarios de junio y septiembre de 2006, por separado y globalmente (tabla 1). En junio se presentaron 106 alumnos, de los cuales 63 pertenecían al grupo AMERAM y 43 al grupo control. En septiembre se presentaron 37 alumnos, 19 del Grupo AMERAM y 18 del grupo control. En el conjunto de ambas convocatorias hubo 130 presentados a examen, 74 del grupo AMERAM y 56 del grupo control. Lo que significa que el porcentaje de alumnos no presentados a examen, entre ambas convocatorias fue el 17\% del grupo AMERAM y el $45 \%$ del grupo control.

TABLA 1. PROYECTO PILOTO: CALIFICACIÓN DEL EXAMEN DE RADIOLOGÍA GENERAL

\begin{tabular}{|lcccccccr|}
\hline & \multicolumn{3}{c}{ Grupo AMERAM } & \multicolumn{3}{c|}{ Grupo Control } & \\
& Media & dst & var & Media & dst & var & T stud \\
\hline & 1,84 & 1,08 & 1,17 & 1,51 & 1,10 & 1,21 & n.s. \\
Junio 2006 & 2,11 & 0,81 & 0,65 & 1,78 & 1,11 & 1,24 & n.s. \\
Septiembre 2006 & 2,11 & 0,85 & 0,73 & 1,73 & 1,04 & 1,07 & $<0,05$ \\
\hline $\begin{array}{l}\text { Ambas } \\
\text { convocatorias }\end{array}$ & & & & & & & & \\
\hline
\end{tabular}

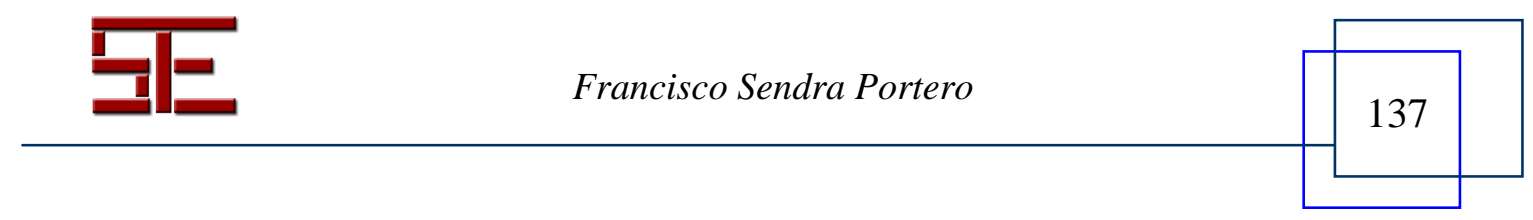




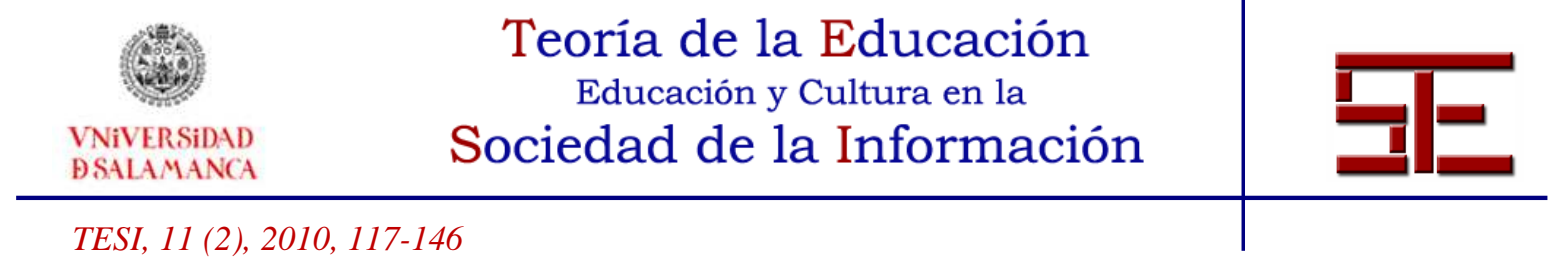

El proyecto fue acogido con entusiasmo por los alumnos participantes en él, los cuales aportaron interesantes ideas para su mejora. Los resultados del grupo AMERAM, considerando ambas convocatorias, han sido significativamente mejores que los del grupo control, aunque la hipótesis de trabajo era que los alumnos obtendrían idénticos resultados académicos. La diferencia obtenida parece obedecer a que los voluntarios participantes en el proyecto fueron, en general, alumnos más activos y motivados. Prueba de ello son las importantes diferencias de participación en el examen. De la experiencia piloto puede concluirse que las clases convencionales pueden sustituirse por el mismo contenido en formato virtual, sin detrimento para los alumnos.

\subsection{La segunda fase}

En el curso académico 2006-2007 y siguientes se ha desarrollado la segunda fase del proyecto. La aplicación de las clases virtuales como una herramienta de uso obligatorio, que se complemente con un nuevo formato de clases presenciales constituye la base de este proyecto educativo. Los alumnos disponen de acceso a las lecciones virtuales, antes y después de las correspondientes clases presenciales. Al inicio del curso, se les explican los objetivos y las características del proyecto, así como la importancia de visitar los contenidos de AMERAM antes de la correspondiente clase presencial. El contenido de las clases presenciales se ha modificado hacia una exposición más dinámica y participativa. Se ha creado una colección de presentaciones PowerPoint (AMERAMplus), siguiendo el guión de la lección virtual correspondiente, pero sin reproducirla exactamente, sino completándola con nuevos ejemplos, más variados. El desarrollo de las clases se conduce haciendo participar a los alumnos con preguntas sobre el tema, estimulando la intervención de éstos.

La dinámica de la clase presencial se inicia recordando a los alumnos los contenidos, con la sinopsis de la página principal. A continuación se comentan los diferentes apartados, forzando la participación de los alumnos mediante la formulación de preguntas. Para agilizar el desarrollo de la clase, se utiliza un ratón inalámbrico de más de 30 metros de alcance, lo que permite al profesor desplazarse por el aula controlando el avance de pantallas, y motivando directamente a los alumnos con su presencia cercana. Algunas de las reglas conductuales de las clases presenciales han sido:

- Impedir la toma de apuntes indiscriminada, sobre todo cuando se comentan ejemplos.

- Indicar las diapositivas "accesorias", por ejemplo aquellas que presentan un listado para indicar exclusivamente que el concepto que se explica es muy amplio.

- Subrayar los contenidos fundamentales del tema.

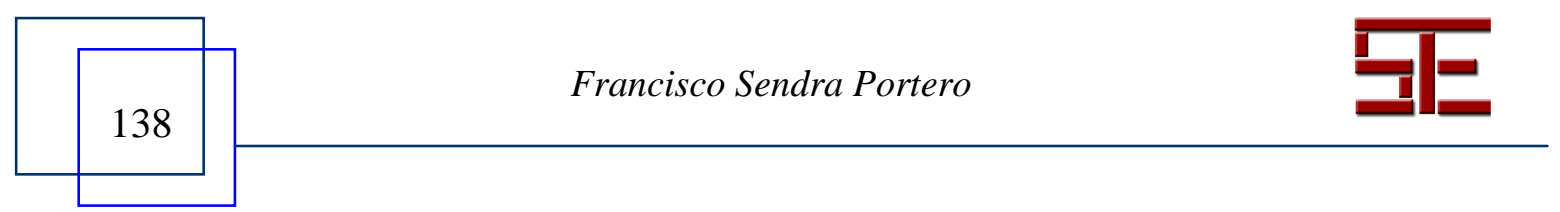




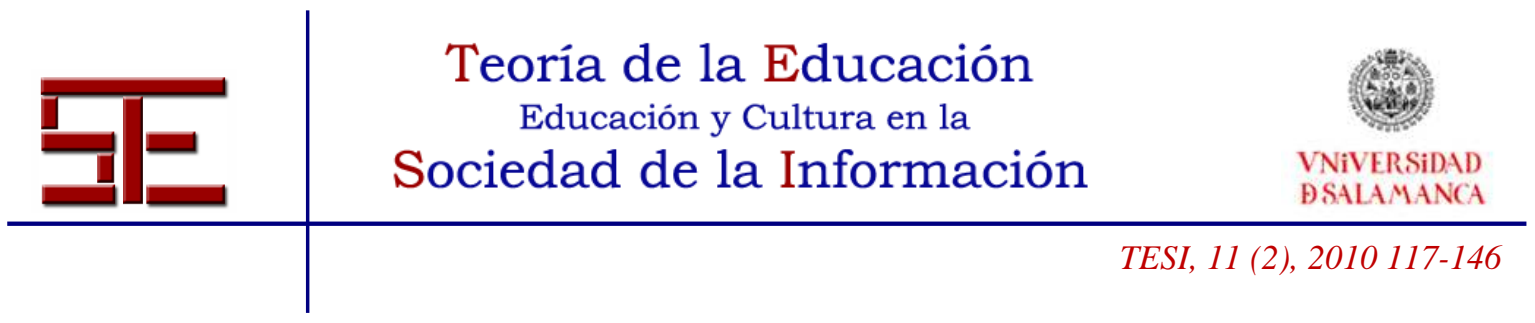

- Hacer referencia frecuente a los contenidos de la clase virtual.

Una ventaja esencial, es evitar que el alumno pase los 45 minutos de clase dedicándose a escribir cada palabra de la explicación del profesor, en detrimento de la atención a los conceptos e imágenes utilizadas como ejemplo. Esta situación suele ser escenario habitual de las clases teóricas, transformadas en una especie de dictado en el que no era infrecuente solicitar a los alumnos que dejaran de escribir para atender a un ejemplo, o que estos pidieran al profesor que repitiera lo último que había dicho y que no pudieron copiar. Con AMERAM, los alumnos acuden con sus propias anotaciones, sin dejar de atender y participar en clase, limitando las anotaciones escritas a unas pocas, complementarias, e incluso formulando dudas, fruto del trabajo en casa con la clase virtual, al inicio de las clases. Se puede concluir que el sistema es efectivo desde un punto de vista académico y formativo.

\subsection{Difusión del proyecto}

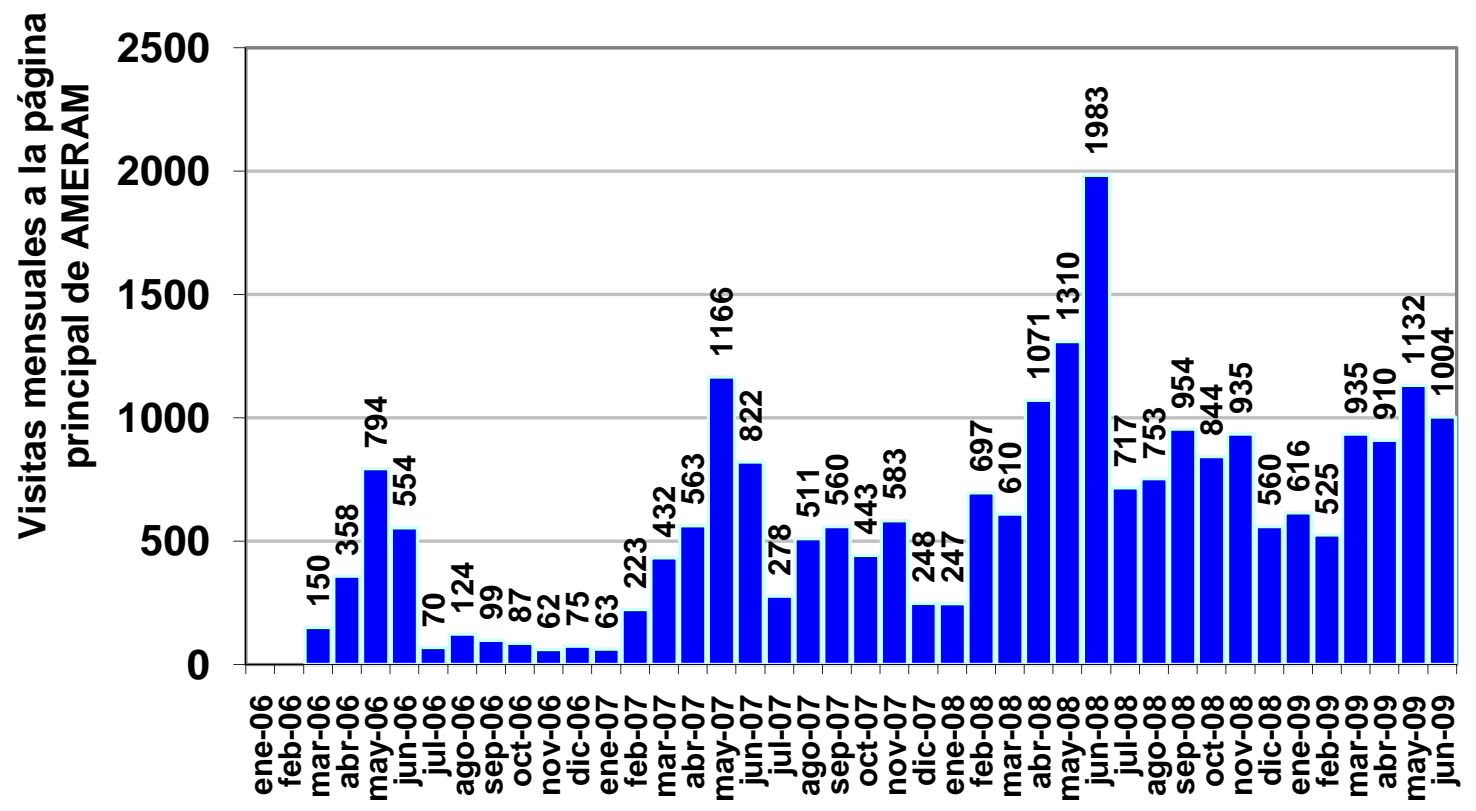

Figura 15.- Visitas mensuales a la página de entrada de AMERAM

http://campusvirtual.uma.es/rgral/ameram.html hasta junio de 2009, fecha en la que dejo de estar activo el primer servidor. Desde julio de 2008 existe otra ubicación "en espejo" en http://wwwrayos.medicina.uma.es/rgral/ameram.html, cuyos accesos no están incluidos en este gráfico.

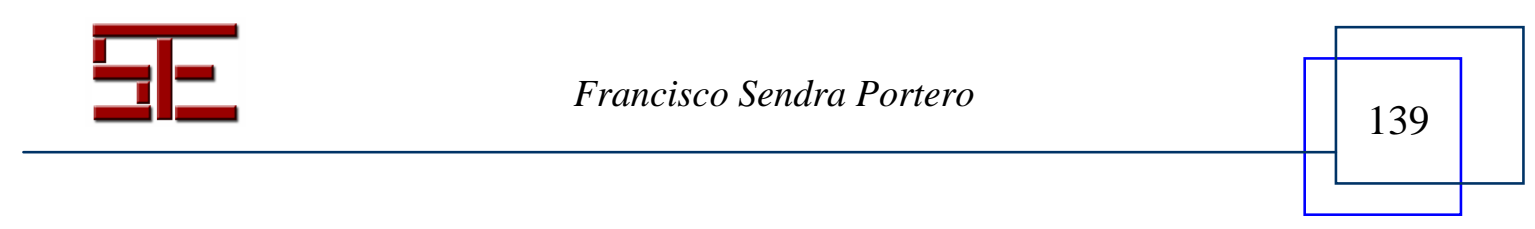




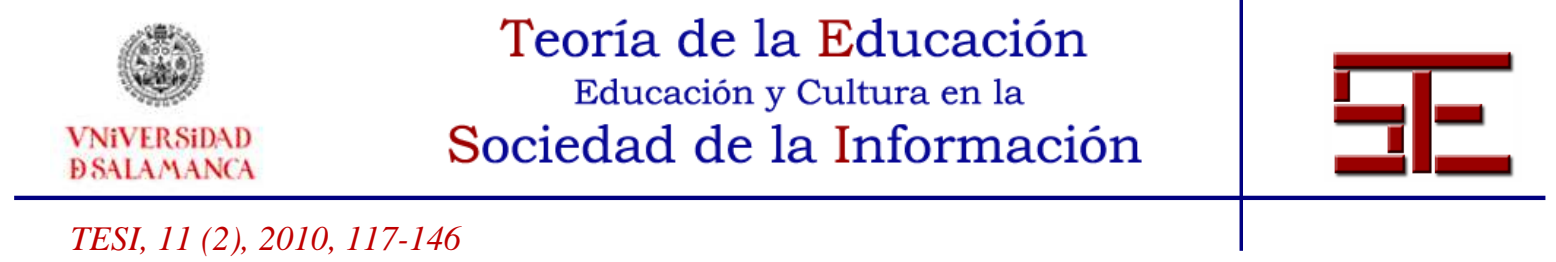

Hasta la fecha, se han iniciado diversas estrategias de difusión de este proyecto, relacionadas con congresos nacionales e internacionales de radiología o de educación médica, o con profesores de Radiología de universidades españolas e hispanoamericanas. En algunas de estas universidades se utiliza actualmente como recurso de consulta, recomendado por los profesores. El número de accesos a AMERAM está siendo cada vez más elevado, con importante participación de alumnos de fuera de la Universidad de Málaga (Fig. 15), lo que supone que este proyecto está siendo un pequeño ejemplo de la universalidad de Internet.

AMERAM presenta los beneficios de la enseñanza virtual sobre la clase tradicional identificados por Ruiz y cols. (2006): i) la posibilidad de aprender en cualquier momento, desde cualquier localización, sin viajar ni desplazarse; ii) una aproximación individualizada, con un ritmo autodirigido, que permite a los alumnos saltar los aspectos conocidos y moverse hacia otros menos familiares; iii) la capacidad de actualizarse fácil y rápidamente, y iv) un enfoque multimedia de la enseñanza que soporta diferentes formatos de información: imagen, gráficos, texto, narración.

La llamada tecnología de Instrucción puede demostrar ser un importante complemento para los métodos tradicionales de enseñanza, pero no es una solución final para la formación (Gunderman y cols, 2001). La finalidad de aplicar nuevas tecnologías en la enseñanza no debe ser reemplazar los profesores sino mejorar su eficacia en la educación. El objetivo del presente proyecto educativo coincide con estos términos, pues AMERAM ha sido diseñado para sustituir las clases convencionales en su formato actual, permitiendo modificarlas y aprovechar el contacto cara a cara de los alumnos y el profesor para fomentar la interacción, generando cuestiones relacionadas con el tema que se han revisado previamente en la clase virtual.

\section{4.- Conclusiones}

AMERAM es un proyecto en curso en nuestra universidad con escasos precedentes en la formación de pregrado, basado en lecciones virtuales de Radiología, con la voz del profesor en audio y acceso on-line. Persigue evaluar las posibilidades que aporta al aprendizaje de radiología en pregrado, el hecho de que el alumno disponga de una copia virtual de la clase tradicional. Hasta ahora ha demostrado ser factible técnicamente.

La experiencia piloto, desarrollada en 2005-2006, ha demostrado que la lección magistral puede sustituirse por un equivalente con contenidos virtuales sin detrimento en la formación académica del alumno. Constantemente se encuentran aspectos que mejorar, y se hace con el estímulo de que la aceptación de los alumnos es excelente. No

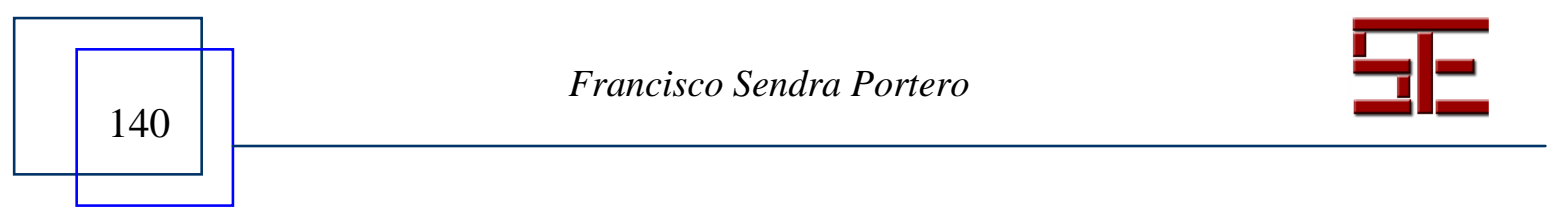




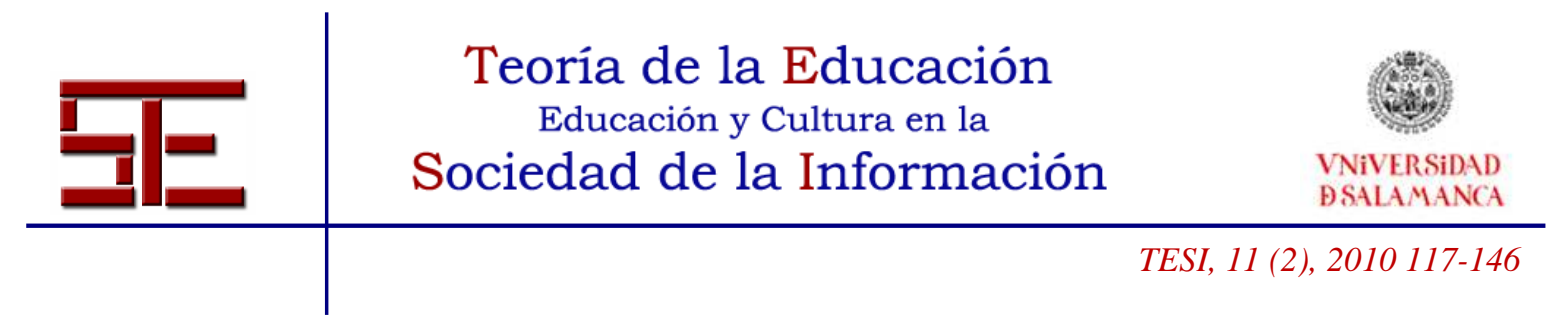

se pretende que las clases virtuales sean un sustituto de las casos presenciales en la enseñanza de Radiología, sino un complemento a éstas, pues la interacción con el profesor y con otros alumnos son elementos fundamentales en el aprendizaje.

Consideramos que la simbiosis entre clase virtual y clase presencial, adaptada una a otra, es muy útil para un mejor aprovechamiento del tiempo dedicado al aprendizaje. Presenta una ventaja fundamental, el alumno puede determinar el ritmo y el momento de estudio de los temas, así como repetir cuantas veces quiera el contenido de las clases. El acceso a sus contenidos es libre para cualquier usuario, lo que permite que lo utilicen alumnos y profesores de toda la comunidad universitaria.

\section{5.- RECOPILACIÓN DE FUENTES DE INFORMACIÓN.}

La información existente en Internet sobre radiología es extremadamente amplia, variada y en ocasiones de dudosa calidad. Dónde buscar información adecuada, es una pregunta que, cada vez con más frecuencia, suelen plantear alumnos a profesores. Por otro lado, no es infrecuente que, documentándose o realizando búsquedas diversas, el profesor encuentre material educativo muy útil para el pregrado. Como consecuencia de estas dos situaciones surgió la idea de crear un portal de recursos educativos de radiología. A este portal se le denominó con el mismo nombre genérico de la asignatura "Radiología General"

\section{1.- Radiología General}

Se trata de una iniciativa sencilla, de gran utilidad, es un portal de recopilación de recursos educativos de radiología pensado para alumnos de medicina, donde se pueden repasar conceptos, ampliar conocimientos, o visitar contenidos educativos de radiología. Proporciona información complementaria, comentada y organizada, al estudiante de medicina.

Es una página Web con marcos estructurada en capítulos. La figura 16 es una captura de pantalla de la página de acceso. En la columna de la izquierda hay una serie de capítulos que van a modificar el marco central y en la página principal se muestran diversos recursos docentes como sugerencias previas, para que el alumno pueda acceder y ver su contenido. El portal es de acceso libre. Algunos de estos recursos son nuestros propios proyectos del Departamento de Radiología de la Universidad de Málaga, expuestos en este trabajo.

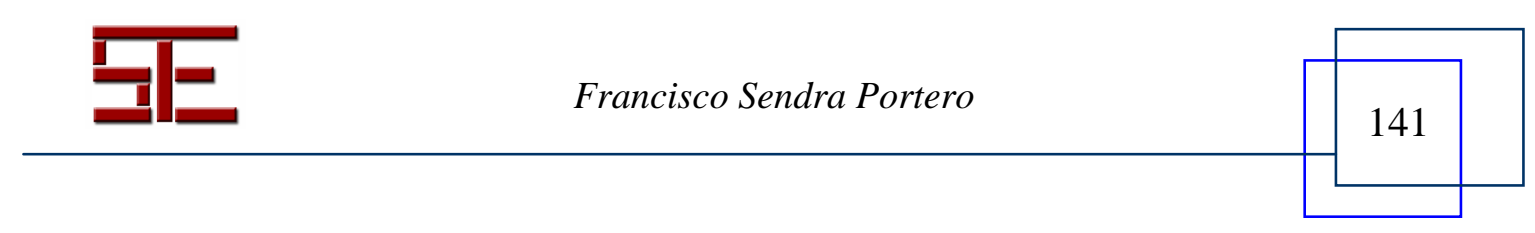




\begin{tabular}{|c|c|c|}
\hline Hitho & $\begin{array}{c}\text { Teoría de la Educación } \\
\text { Educación y Cultura en la }\end{array}$ & \\
\hline $\begin{array}{l}\text { VNiVERSIDAD } \\
\text { BSALAMANCA }\end{array}$ & Sociedad de la Información & \\
\hline
\end{tabular}

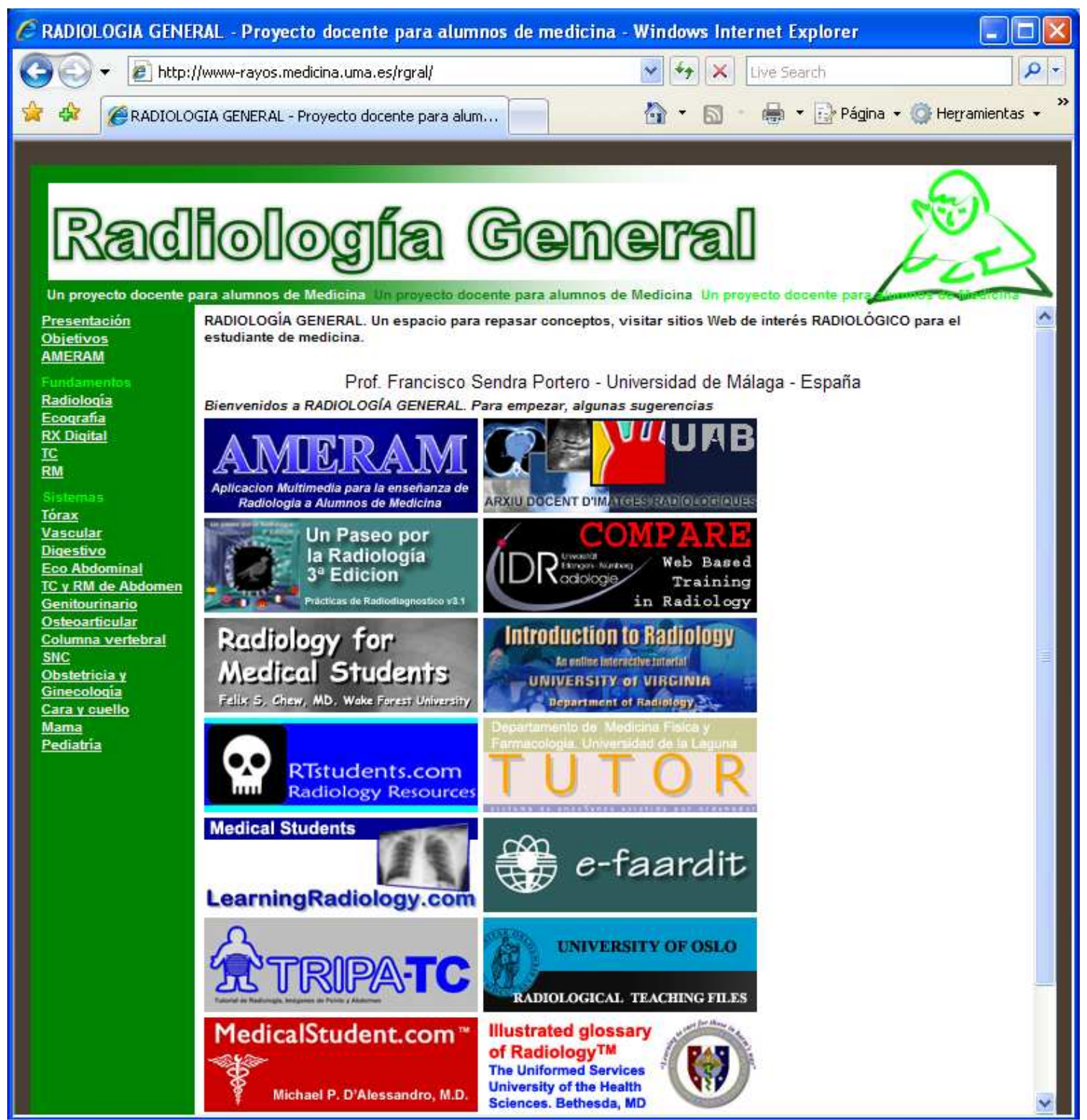

Figura 16.- Captura de pantalla del portal Radiología General, dedicado a recopilar recursos educativos de Radiología para Estudiantes de Medicina.

\section{6.- REFLEXIONES FINALES}

Las aplicaciones multimedia tienen una propiedad básica, la interactividad, de forma que el usuario controla el progreso de las diferentes acciones dispuestas sobre la

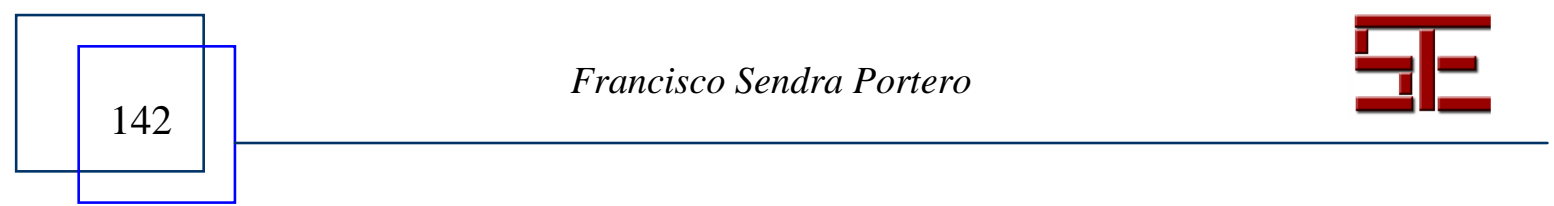




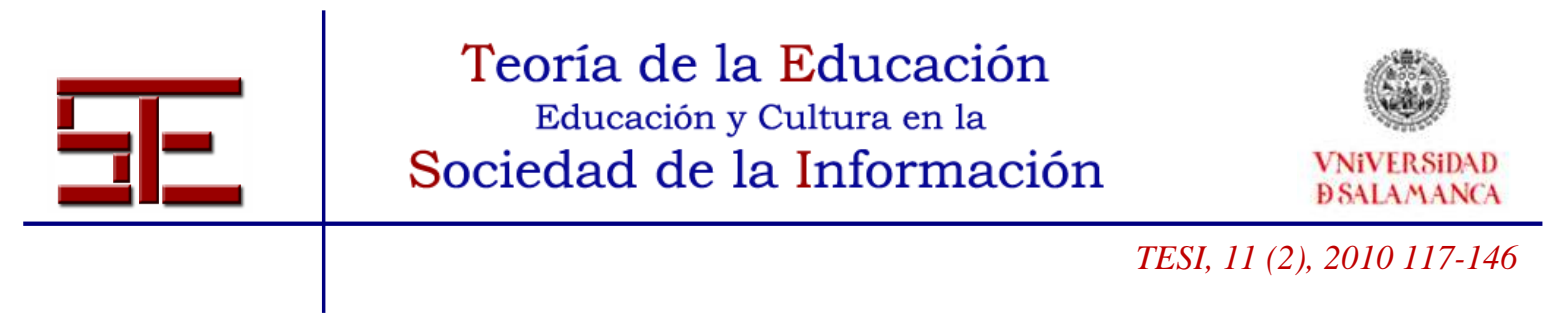

pantalla mediante objetos activos. Por ello, los sistemas multimedia son especialmente flexibles para adaptarlos al proceso enseñanza-aprendizaje. El alumno puede decidir el ritmo de acontecimientos de una aplicación y la dirección que tomará su sesión de aprendizaje en función de sus necesidades. Complementariamente, la interfaz de usuario constituye un elemento importante para que una aplicación educativa sea agradable, intuitiva y fácil de utilizar, proporcionando una actitud positiva del usuario.

Los seminarios y prácticas en grupos pequeños, o las tutorías personales son elementos básicos para desarrollar este aspecto de la enseñanza en Radiología. Esta formación práctica requiere una comprensión muy específica de cada alumno, con la subsiguiente necesidad de atención, casi individualizada y consumo de tiempo y esfuerzo del profesorado (Otón Sánchez y cols, 1999). En este punto, la enseñanza electrónica proporciona un elemento infatigable, que facilita la progresión individual del alumno en el aprendizaje.

El proceso de creación de herramientas docentes, incluyendo el planteamiento de objetivos educativos, el estudio de productos de características similares, evaluación por expertos y usuarios, así como la elaboración, modificación y mejora de contenidos, constituye un ciclo de investigación que requiere una gran dedicación personal. Esto hace que este tipo de estudios sea adecuado para el desarrollo de proyectos de tesis doctorales, contribuyendo a la capacitación de los doctores en el desarrollo y creación de material educativo en formato electrónico.

Desde 1999 hemos implicado nuestro programa del doctorado en ello, favoreciendo la creación de cursos y líneas de investigación específicas y el desarrollo de tesis doctorales relacionadas con proyectos de enseñanza y aprendizaje electrónico (Algarra García, 1998; Navarro Sanchis, 2005; Torales Chaparro, 2009), e intentando, en lo posible, difundir estos proyectos en revistas de impacto (Navarro Sanchis y Sendra Portero, 2005).

Crear herramientas educativas es un trabajo intenso que en el ámbito universitario no suele ser lucrativo. Por ello la difusión de este tipo de proyectos es importante y a veces la única recompensa junta al agradecimiento de los alumnos. Por otra parte, la difusión va enlazada al contacto con docentes y alumnos (creadores de recursos y usuarios) que tengan cierto nivel de interés en estas tecnologías.

La creación de grupos colaborativos rentabilizaría en gran medida los esfuerzos de todas las fases de este tipo de proyectos: creación-uso-evaluación-optimización-usoevaluación-... La difusión de herramientas educativas multimedia y de aprendizaje 'on line' en Europa pasa necesariamente por la traducción de dichas herramientas. En

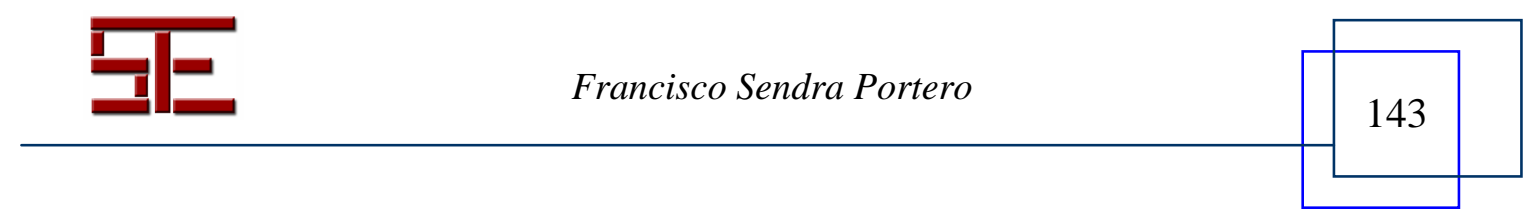




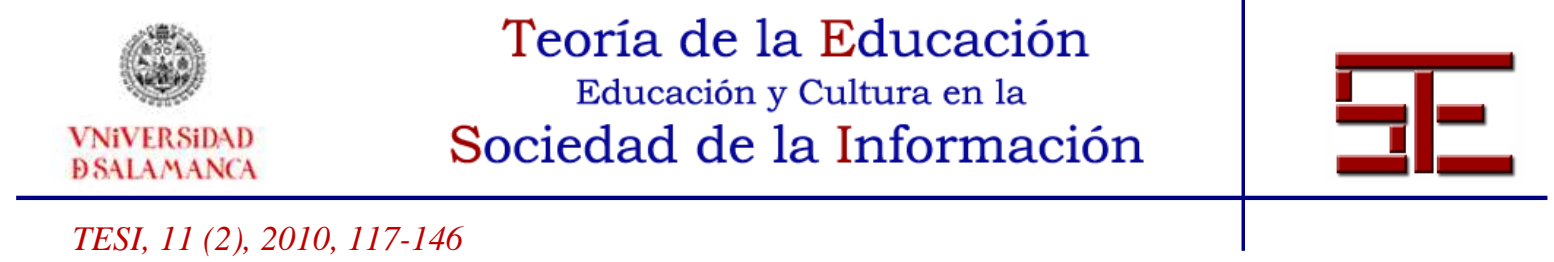

nuestra opinión no hay aprendizaje tan intuitivo y agradable como el que se realiza en la lengua materna. "Intuitivo" y "agradable" son precisamente dos características deseables en las herramientas de aprendizaje electrónico. Como parte de la estrategia de difusión, se ha abordado la traducción multilingüe de algunas aplicaciones, implicando a profesores de Traducción e Interpretación de la Universidad de Málaga, alumnos de otras universidades Europeas (Universidad de Rennes2), profesores de radiología de otras nacionalidades y alumnos de radiología del programa Erasmus.

Reconocemos la falta de conocimiento adecuado de cómo conseguir recursos para captar "socios" en Europa. El escenario habitual es que se encuentren compañeros con inquietudes y/o proyectos similares en reuniones profesionales, donde se inician contactos personales. Pero es realmente costoso en tiempo y esfuerzo conocer el trámite administrativo y utilizar adecuadamente las vías necesarias para apoyar iniciativas de colaboración entre socios europeos. Hispanoamérica es otro ámbito de difusión en el que pueden tener cabida importantes proyectos colaborativos de aprendizaje electrónico.

Hemos expuesto algunas experiencias relacionadas con la enseñanza de Radiología en pregrado, que han contribuido a mejorar las posibilidades educativas en la licenciatura de medicina en nuestro centro y han proporcionado herramientas de formación a estudiantes, médicos y residentes y especialistas de radiología.

La filosofía de aprendizaje del Espacio Europeo de Enseñanza Superior, centrada en el alumno y basada en el autoaprendizaje, da una importancia vital a las herramientas electrónicas de formación en pregrado. Cómo conseguir ingresos adecuados para continuar con el desarrollo de estas herramientas docentes en un contexto de difusión aplicación y estudio a nivel nacional e internacional o cómo implicar a empresas e instituciones en esta tarea, son cuestiones que nos sigue preocupando desarrollar en el contexto de estas experiencias.

\section{7.- BIBLIOGRAFÍA}

Algarra García, J. (1998). Una aplicación multimedia para la docencia de la TC de tórax. Tesis doctoral. Universidad de Málaga.

Algarra García, J., Ristori Bogajo, E. Y Sendra Portero, F. (1999). Una aplicación multimedia para la docencia de la TC de tórax: evaluación de usuarios. En Sendra Portero, F., Navabaro, E. y Mrtínez Morillo, M. (eds). Radiología Digital. Servicio de Publicaciones e Intercambio Científico de la Universidad de Málaga: Málaga. 309-336.

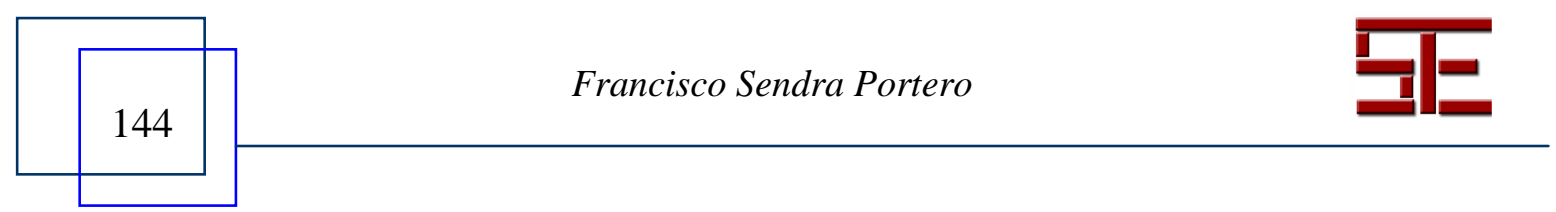




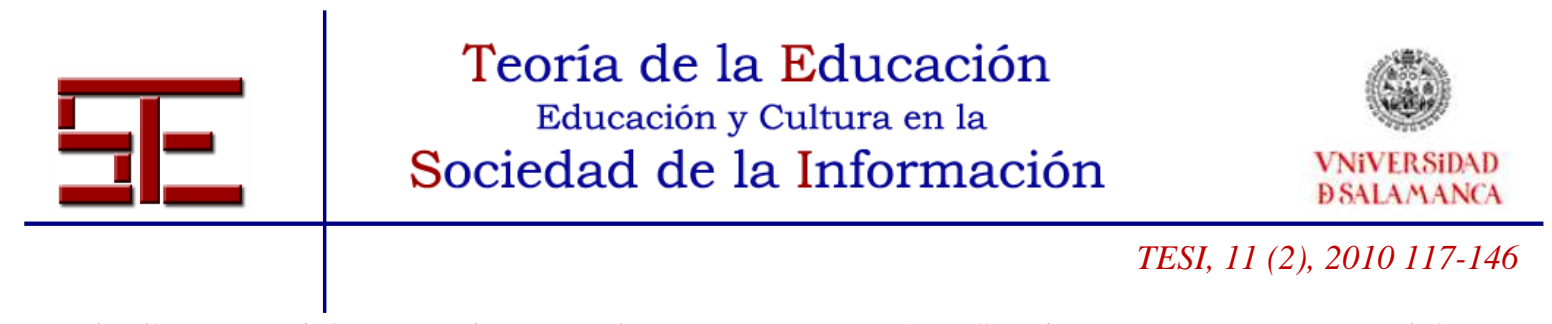

Del Cura Rodríguez, Jl., Martínez Noguera, A., Sendra Portero, F., Rodríguez González, R., Puig Domingo, J. Y Alguersuari Cabiscol, A (2008). La enseñanza de la Radiología en los estudios de la Licenciatura en Medicina. Informe de la Comisión de Formación de la SERAM. Radiología, 50:177-182.

Gunderman, R. B., Kang, Y. P., Fraley, R. E. Y Williamson, KB. (2001). Instructional Technology and Radiologic Education. Radiology; 221(1):1-4.

Martínez Morillo, M. Y Sendra Portero, F. (2000). Un paseo por la Radiología. Prácticas de Radiodiagnóstico v 1.1. Servicio de Publicaciones e Intercambio Científico de la Universidad de Málaga. Málaga.

- (2002): Un paseo por la Radiología $2^{a}$ Edición. Prácticas de Radiodiagnóstico v 2.1. Servicio de Publicaciones e Intercambio Científico de la Universidad de Málaga. Málaga.

Navarro Sanchis, E. L. (2005). Álbum de signos radiológicos. Aplicación multimedia con fines docentes sobre semiología radiológica. Tesis doctoral. Universidad de Málaga.

Navarro Sanchis, E. L. Y Sendra Portero, F. (2005). Album of radiologic signs: a usefull tool for training in radiologic semiology. Radiographics, 25: 257-262.

- (2006): Álbum de signos radiológicos v 2.1. Servicio de Publicaciones e Intercambio Científico de la Universidad de Málaga. Málaga.

Oton Sánchez, C., Oton Sánchez, L. F. Y De Armas González, C. (1999). Inteligencia artificial y sistemas expertos en la enseñanza práctica de la radiología. En Sendra Portero, F., Nava Baro E. y Martínez Morillo, M. (Eds.). Radiología Digital. Servicio de Publicaciones e intercambio científico, Universidad de Málaga, 281-290.

Ruiz, J.G., Mintzer, M. J. Y Leipzig, R. M. (2006). The impact of e-learning in medical education. Acad Med; 81(3):207-212.

Torales Chaparro, O. E. (2009). Diseño y evaluación de una aplicación multimedia para la enseñanza de radiología a alumnos de medicina (AMERAM). Tesis doctoral. Universidad de Málaga.

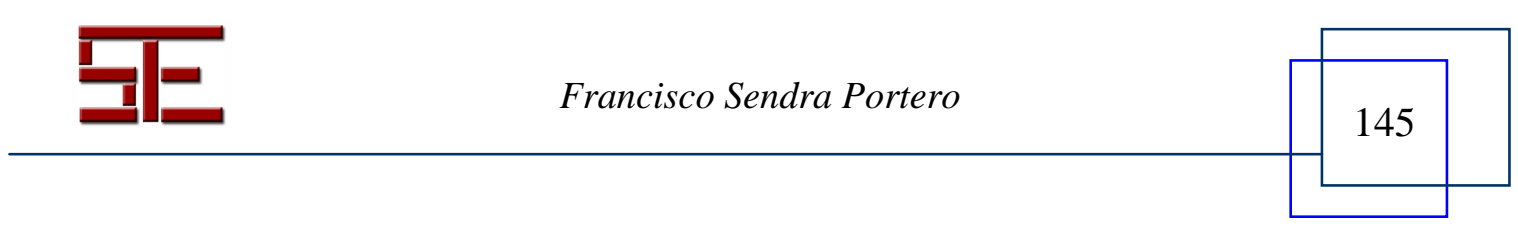




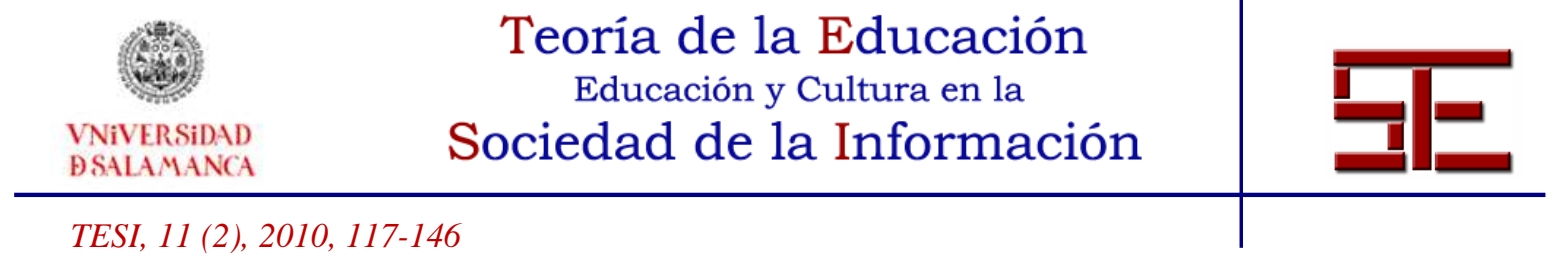

Para citar el presente artículo puede utilizar la siguiente referencia:

Sendra Portero, F. (2010).: Enseñanza electrónica de radiología en pregrado: la experiencia de la Universidad de Málaga, en Juanes Méndez, J. A. (Coord.) Avances tecnológicos digitales en metodologías de innovación docente en el campo de las Ciencias de la Salud en España. Revista Teoría de la Educación: Educación y Cultura en la Sociedad de la Información. Vol. $11, \mathrm{n}^{\circ}$ 2. Universidad de Salamanca, pp. 117-146 [Fecha de consulta: dd/mm/aaaa]. http://campus.usal.es/ revistas_trabajo/index.php/revistatesi/article/view/7074/7107

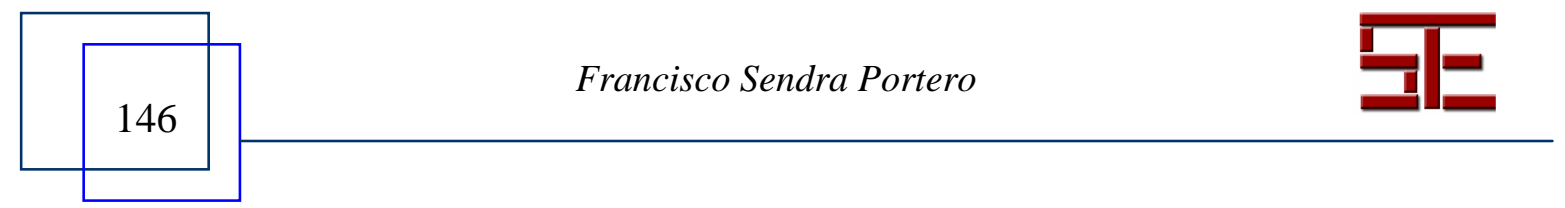

